\title{
Cyanobacteria of the 2016 Lake Okeechobee and Okeechobee Waterway Harmful Algal Bloom
}

Open-File Report 2017-1054 
Cover. Photomicrograph of Dolichospermum circinale collected July 9, 2016, from Lake Okeechobee, Florida. These living cells in a coiled filament are illuminated with wide-blue epifluorescence microscopy. Pigments in the cells glow yellow in vegetative cells, which have small orange spots - the aerotopes, and round red cells - the heterocytes. 


\section{Cyanobacteria of the 2016 Lake Okeechobee and Okeechobee Waterway Harmful Algal Bloom}

By Barry H. Rosen, Timothy W. Davis, Christopher J. Gobler, Benjamin J. Kramer, and Keith A. Loftin

Open-File Report 2017-1054 


\title{
U.S. Department of the Interior \\ RYAN K. ZINKE, Secretary
}

\section{U.S. Geological Survey William H. Werkheiser, Acting Director}

\author{
U.S. Geological Survey, Reston, Virginia: 2017
}

For more information on the USGS - the Federal source for science about the Earth, its natural and living resources, natural hazards, and the environment—visit http://www.usgs.gov or call 1-888-ASK-USGS.

For an overview of USGS information products, including maps, imagery, and publications, visit http://www.usgs.gov/pubprod/.

Any use of trade, firm, or product names is for descriptive purposes only and does not imply endorsement by the U.S. Government.

Although this information product, for the most part, is in the public domain, it also may contain copyrighted materials as noted in the text. Permission to reproduce copyrighted items must be secured from the copyright owner.

Suggested citation:

Rosen, B.H., Davis, T.W., Gobler, C.J., Kramer, B.J., and Loftin, K.A. , 2017, Cyanobacteria of the 2016 Lake Okeechobee Waterway harmful algal bloom: U.S. Geological Survey Open-File Report 2017-1054, 34 p., https://doi. org/10.3133/ofr20171054.

ISSN 2331-1258 (online) 


\section{Acknowledgments}

The U.S. Geological Survey (USGS) has undertaken the task of documenting the cyanobacteria of the 2016 Lake Okeechobee and Okeechobee Waterway bloom in a readily available digital format. These images and associated names are needed for current and future research on algal blooms. This project was funded by the USGS Priority Ecosystem Study program.

The authors are grateful for the taxonomic advice and thorough review of Sue Watson with Environment and Climate Change, Canada (ret.), Ann St. Amand with PhycoTech, and Jennifer L. Graham with the U.S. Geological Survey (USGS).

Samples were provided by Bruce Sharfstein of the South Florida Water Management District and Travis Knight and Robert Clendening of the USGS Caribbean-Florida Water Science Center.

This project was funded by the USGS Priority Ecosystem Study program and USGS Environmental Health Toxic Substances Hydrology Program. 



\section{Contents}

Abstract
Introduction
Methods
Field Samples
Morphologically Based Taxonomy
Organisms
References

\section{Figures}

1. Locations of the water samples taken from Lake Okeechobee and the Lake Okeechobee Waterway for the photomicrographs in this publication ...............................

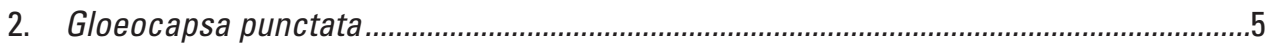

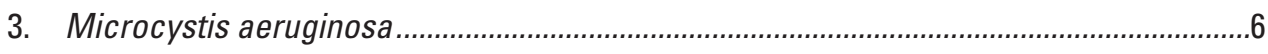

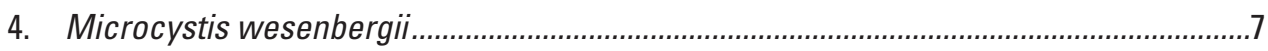

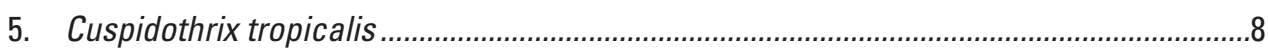

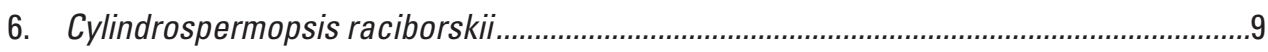

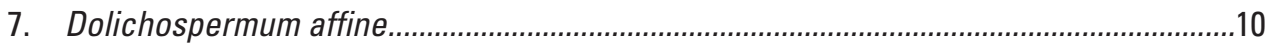

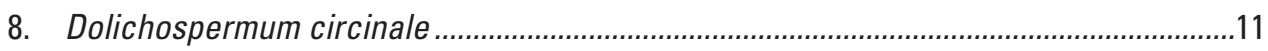

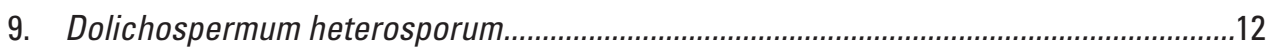

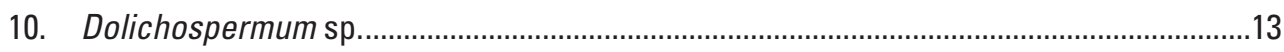

11. Fortiea monilispora

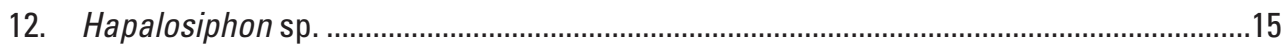

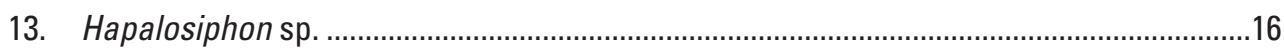

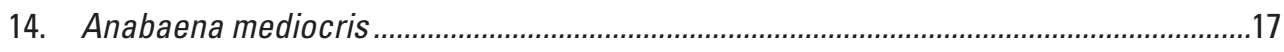

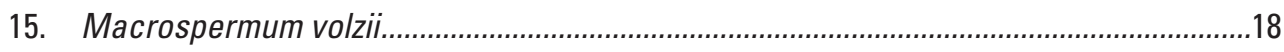

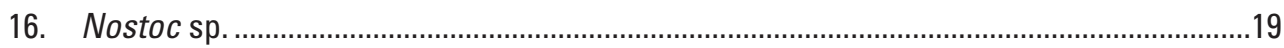

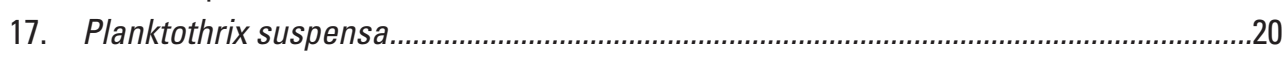

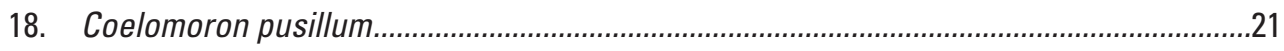

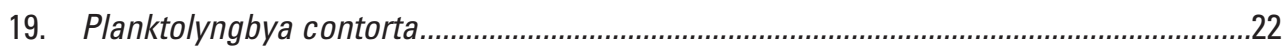

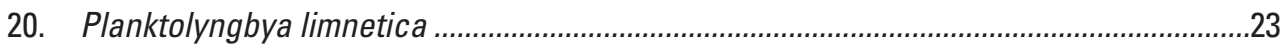

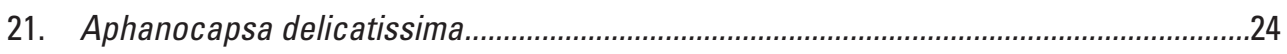

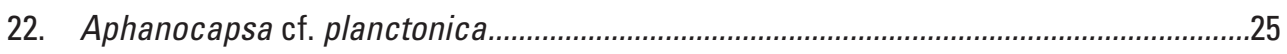

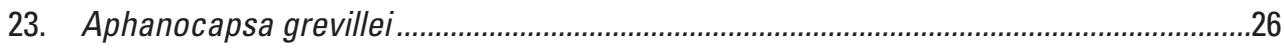

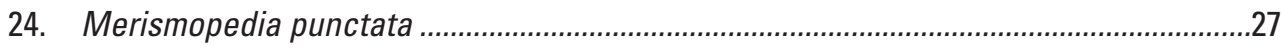

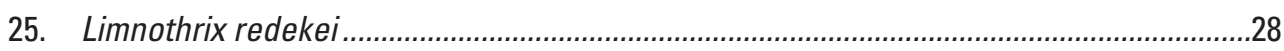

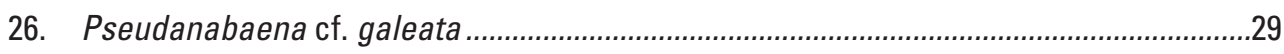

27. Pseudanabaena mucicola

28. Pseudanabaena $\mathrm{sp}$................................................................................................. 


\section{Tables}

1. Sample date, site identification, latitude and longitude, and source for sample collections.

\section{Conversion Factors}

International System of Units to U.S. customary units

\begin{tabular}{|c|c|c|}
\hline Multiply & By & To obtain \\
\hline \multicolumn{3}{|c|}{ Length } \\
\hline millimeter $(\mathrm{mm})$ & 0.03937 & inch (in.) \\
\hline \multicolumn{3}{|c|}{ Volume } \\
\hline liter $(\mathrm{L})$ & 33.81402 & ounce, fluid (fl. oz) \\
\hline liter $(\mathrm{L})$ & 2.113 & $\operatorname{pint}(\mathrm{pt})$ \\
\hline liter (L) & 1.057 & quart (qt) \\
\hline liter (L) & 0.2642 & gallon (gal) \\
\hline
\end{tabular}

Temperature in degrees Celsius $\left({ }^{\circ} \mathrm{C}\right)$ may be converted to degrees Fahrenheit $\left({ }^{\circ} \mathrm{F}\right)$ as

$$
{ }^{\circ} \mathrm{F}=\left(1.8 \times{ }^{\circ} \mathrm{C}\right)+32 .
$$

\section{Abbreviations}

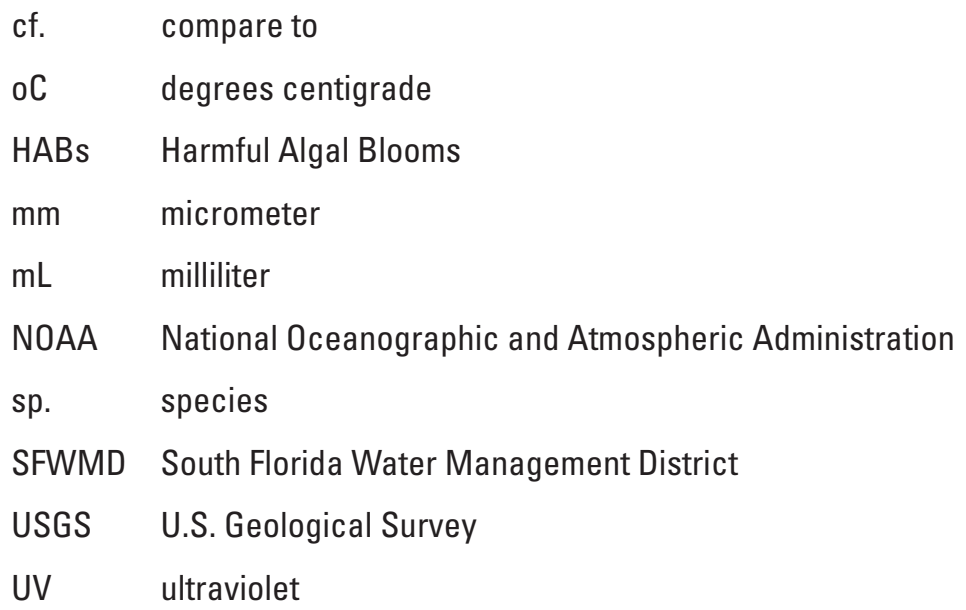




\title{
Cyanobacteria of the 2016 Lake Okeechobee and Okeechobee Waterway Harmful Algal Bloom
}

\author{
By Barry H. Rosen', Timothy W. Davis², Christopher J. Gobler ${ }^{3}$, Benjamin J. Kramer ${ }^{3}$ and Keith A. Loftin ${ }^{4}$
}

\section{Abstract}

The Lake Okeechobee and the Okeechobee Waterway (Lake Okeechobee, the St. Lucie Canal and River, and the Caloosahatchee River) experienced an extensive harmful algal bloom within Lake Okeechobee, the St. Lucie Canal and River and the Caloosahatchee River in 2016. In addition to the very visible bloom of the cyanobacterium Microcystis aeruginosa, several other cyanobacteria were present. These other species were less conspicuous; however, they have the potential to produce a variety of cyanotoxins, including anatoxins, cylindrospermopsins, and saxitoxins, in addition to the microcystins commonly associated with Microcystis. Some of these species were found before, during, and 2 weeks after the large Microcystis bloom and could provide a better understanding of bloom dynamics and succession. This report provides photographic documentation and taxonomic assessment of the cyanobacteria present from Lake Okeechobee and the Caloosahatchee River and St. Lucie Canal, with samples collected June 1st from the Caloosahatchee River and Lake Okeechobee and in July from the St. Lucie Canal. The majority of the images were of live organisms, allowing their natural complement of pigmentation to be captured. The report provides a digital image-based taxonomic record of the Lake Okeechobee and the Okeechobee Waterway microscopic flora. It is anticipated that these images will facilitate current and future studies on this system, such as understanding the timing of cyanobacteria blooms and their potential toxin production.

\footnotetext{
${ }^{1}$ U.S. Geological Survey, Southeast Region

${ }^{2}$ National Ocean and Atmospheric Administration, Great Lakes Environmental Research Laboratory

${ }^{3}$ Stony Brook School of Marine and Atmospheric Sciences

${ }^{4}$ U.S. Geological Survey, Kansas Water Science Center, Organic Geochemistry Research Laboratory
}

\section{Introduction}

Lake Okeechobee has long been classified as a eutrophic water body (Canfield and Hoyer, 1988). One consequence of nutrient pollution and degraded water quality is the formation of harmful algal blooms (HABs), which occur when the optimal balance of nutrients, light, water column stability and temperature allow any algae or cyanobacteria in the water column to be stimulated and grow more rapidly than neighboring species (Reynolds, 1984). In freshwater systems, HABs are generally dominated by cyanobacteria (also called blue-green algae), often referred to as "CyanoHABs." Cyanobacteria are true bacteria; however, they contain chlorophyll $a$, and thus were initially classified as algae. They are primary producers like the eukaryotic algae, and performing photosynthesis is common to both types of organisms. Many species of bloom-forming cyanobacteria can regulate their buoyancy, moving down in the water column at night to scavenge phosphorus released from sediments and up in the water column during the day to maximize photosynthesis. As bacteria, they also thrive when temperatures are warm (Visser and others, 2016). One order of cyanobacteria (Nostocales) can also fix atmospheric nitrogen through a specialized cell, the heterocyte, which provides this key element for growth when it is in limited supply, allowing this group to have an advantage over other cyanobacteria and eukaryotic algae. It should be noted that a few species of cyanobacteria without a heterocyte can also fix nitrogen. The ability to regulate their buoyancy, temperature tolerance, and nitrogen fixation are three ecological strategies that give cyanobacteria advantages that allow them to out-compete eukaryotic algae.

CyanoHABs have been documented in Lake Okeechobee and Okeechobee Waterway (Lake Okeechobee, the St. Lucie Canal and River, and the Caloosahatchee River) since the early 1980s (Havens and others, 1995a, b), which are frequently dominated by Microcystis aeruginosa (Havens and others, 2016, Philips and others, 2012). Many species of cyanobacteria are present in the Lake Okeechobee 
Waterway although no recent study has documented the richness of the cyanobacterial community. It is important to understand taxonomic diversity, as many cyanobacteria can produce a variety of cyanotoxins, including neurotoxins and hepatotoxins such as anatoxins, cylindrospermopsins, and saxitoxins, in addition to microcystins and other potentially harmful metabolites (see reviews by O'Neil and others, 2012; Pearson and others, 2016). The functions of these toxins to the cyanobacteria are the subject of much speculation and no single hypothesis has proven correct (Pearson and others, 2016). The stimulation of toxin production by an organism with the genes for its production also is under intense investigation (Davis and others 2009, 2010, 2015; Harke and Gobler, 2015; Gobler and others, 2016; Pearson and others, 2016).

The photographic documentation and taxonomic assessment of the species (Rosen and Mareš, 2016) present in various locations during the 2016 bloom in the Lake Okeechobee and the Okeechobee waterway can be used to guide future studies and toxin monitoring programs (Rosen and St. Amand, 2015).

\section{Methods}

\section{Field Samples}

Grab samples of live phytoplankton were collected by either submersing a 1-liter polypropylene bottle at the water surface to capture the uppermost portion of the water column or by using a vertical Van Dorn water sampler to collect the bloom water just below the surface. Three sets of samples were collected on the following dates: June 1, 2016, from the Caloosahatchee River; July 5, 2016, from 5 locations in Lake Okeechobee, and July 9-10, 2016, from Lake Okeechobee locations (Canal Point and Port Mayaca) and down the length of the St. Lucie Canal from S-308 to the estuary (table 1, figure 1). Samples were kept cold and dark after collection, then transported to the laboratory at the Caribbean-Florida Water Science Center, Orlando, Florida, within 48 hours.

Table 1. Sample date, site identification, latitude and longitude, and source for sample collections. Site designations for the Lake Okeechobee sites are from the South Florida Water Management District. Samples from the St. Lucie River and Canal were collected by the National Oceanic and Atmospheric Administration.

[USGS, U.S. Geological Survey; SFWMD, South Florida Water Management District; NOAA, National Oceanic and Atmospheric Administration; SLR, St. Lucie River (Numeral following "SLR" indicates distance from Lake Okeechobee in miles)]

\begin{tabular}{llccl}
\hline \multicolumn{1}{c}{ Date } & Site Identification & Latitude decimal degrees & Longitude decimal degrees & Source \\
\hline $6 / 1 / 2016$ & Caloosahatchee River & 26.7217 & -81.6939 & USGS \\
$7 / 5 / 2016$ & LZ30 & 26.817404 & -80.889917 & SFWMD \\
$7 / 5 / 2016$ & L002 & 27.0827 & -80.7942 & SFWMD \\
$7 / 5 / 2016$ & L005 & 26.9567 & -80.9724 & SFWMD \\
$7 / 5 / 2016$ & S-308 & 26.986637 & -80.6102 & SFWMD \\
$7 / 5 / 2016$ & Pahokee Marina & 26.824972 & -80.667711 & SFWMD \\
$7 / 9 / 2016$ & Canal Point & 26.864296 & -80.63255 & NOAA \\
$7 / 9 / 2016$ & Port Mayaca & 26.984979 & -80.620918 & NOAA \\
$7 / 9 / 2016$ & SLR 1 & 27.115429 & -80.2819 & NOAA \\
$7 / 9 / 2016$ & SLR 3 & 27.13966 & -80.261706 & NOAA \\
$7 / 9 / 2016$ & SLR 4 & -80.25502 & NOAA \\
$7 / 9 / 2016$ & SLR 5 & -80.25821 & NOAA \\
$7 / 9 / 2016$ & SLR 6 & 27.15646 & -80.26478 & NOAA \\
$7 / 9 / 2016$ & SLR 6.5 & 27.17855 & -80.264114 & NOAA \\
$7 / 9 / 2016$ & SLR 7 & 27.19989 & -80.26859 & NOAA \\
$7 / 9 / 2016$ & SLR 8 & 27.20684 & -80.33047 & NOAA \\
$7 / 9 / 2016$ & SLR 9 & 27.2608 & -80.29655 & NOAA \\
$7 / 9 / 2016$ & SLR 10 & 27.22998 & -80.25105 & NOAA \\
$7 / 9 / 2016$ & SLR 11 & 27.20792 & -80.21291 & NOAA \\
$7 / 9 / 2016$ & SLR 12 & 27.20509 & -80.19385 & NOAA \\
$7 / 9 / 2016$ & SLR 13 & 27.16769 & -80.16748 & NOAA \\
$7 / 10 / 2016$ & SLR 14 & 27.16516 & -80.455056 & NOAA \\
$7 / 10 / 2016$ & SLR 15 & 27.012359 & -80.296074 & NOAA \\
\hline
\end{tabular}




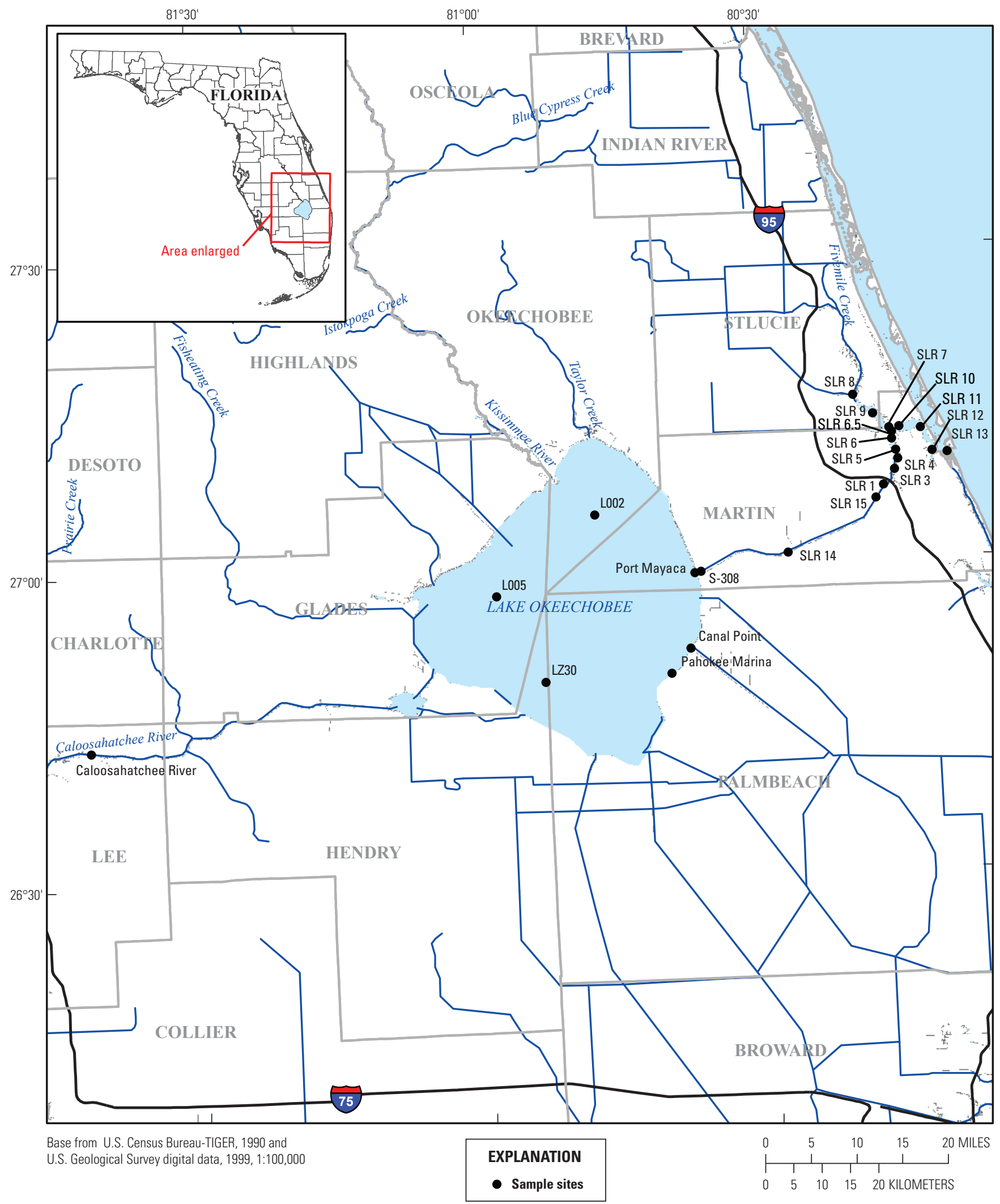

Figure 1. Locations of the water samples taken from Lake Okeechobee and the Lake Okeechobee Waterway for the photomicrographs in this publication. 


\section{Morphologically Based Taxonomy}

Cyanobacteria were identified by morphological traits such as the dimensions (length and width) of cells, the arrangement of cells in colonies or filaments, the terminal cell shape in a filament, and the presence of specialized structures such as aerotopes (also known as gas vesicles used for regulating buoyancy), heterocytes (specialized cells for nitrogen fixation), and akinetes (specialized resting cells that allow organisms to survive harsh conditions and germinate when environmental conditions allow). The dimensions and shape of these specialized cells are critical to the identification of a species. Several sources were used to identify organisms on the basis of morphology (Komárek and Anagnostidis, 1998, 2005; Komárek, 1984, 2008, 2013; Komárek and others, 2014). The classification and groupings of the images are aligned alphabetically by order, family within the order, and genus within the family. The abbreviation "cf." in some of the figure captions is commonly read as "compare with." Collectively, the images are in 4 orders, 10 families, and 17 genera:

\section{Order Chroococcales}

Family Microcystaceae

Genus Gloeocapsa

Genus Microcystis

\section{Order Nostocales}

Family Aphanizomenonaceae

Genus Cuspidothrix

Genus Cylindrospermopsis

Genus Dolichospermum

Family Fortiaceae

Genus Fortiea

Family Hapalosiphonaceae

Genus Hapalosiphon

Family Nostocaceae

Genus Anabaena

Genus Macrospermum

Genus Nostoc

\section{Order Oscillatoriales}

Family Microcoleaceae

Genus Planktothrix

\section{Order Synechococcales}

Family Coelosphaeriaceae

Genus Coelomoron

Family Leptolyngbyaceae

Genus Planktolyngbya

Family Merismopediaceae

Genus Aphanocapsa

Genus Merismopedia

Family Pseudanabaenaceae

Genus Limnothrix

Genus Pseudanabaena

With the live samples, some of the morphological traits needed to identify an organism to the species level were lacking, especially in the filamentous Order Nostocales. To induce the formation of these traits, short-term incubations were performed as follows: (1) Raw samples (approximately 30 milliliters $(\mathrm{mL})$ were poured into their own 90 millimeter $(\mathrm{mm})$ diameter sterile plastic petri dish and incubated in indirect sunlight at 24 degrees Celsius $\left({ }^{\circ} \mathrm{C}\right) ;(2)$ incubated samples were monitored for the formation of key morphological features needed for taxonomic identification to species; and (3) a subset of key organisms of interest was isolated from relevant environmental samples by using aseptic methods following Stein (1973). Briefly, native water from the matching environmental samples was sterile filtered and used as media for each isolate. Water was sterile filtered by using a $250 \mathrm{~mL}$ Nalgene ${ }^{\circledR}$ Rapid-Flow sterile disposable filter 0.2 micrometer $(\mu \mathrm{m})$ nylon membrane ( $50 \mathrm{~mm}$ diameter filter) and stored at $4^{\circ} \mathrm{C}$ until isolates were added.

\section{Microscopy}

Samples initially were observed and photographed by differential interference contrast (DIC) microscopy by using an Olympus BX51 research microscope (Olympus America, Waltham, Massachusetts, USA), at 200x, 400x, 600x (oil), or 1,000x (oil) magnifications (Rosen and others, 2010). Images were all illuminated with DIC, unless otherwise noted. A micrometer scale bar was embedded in the images. The accuracy of the embedded scale was verified with a stage micrometer.

Some cells were further examined and photographed under epifluorescence microscopy with a U-MWU2: Ultraviolet (UV) cube, with excitation wavelengths 330385 nanometers and emission above 515 nanometer. The illumination source was a xenon lamp (X-Cite Series 120Q). 


\section{Organisms}

Order Chroococcales

Family Microcystaceae

Genus Gloeocapsa

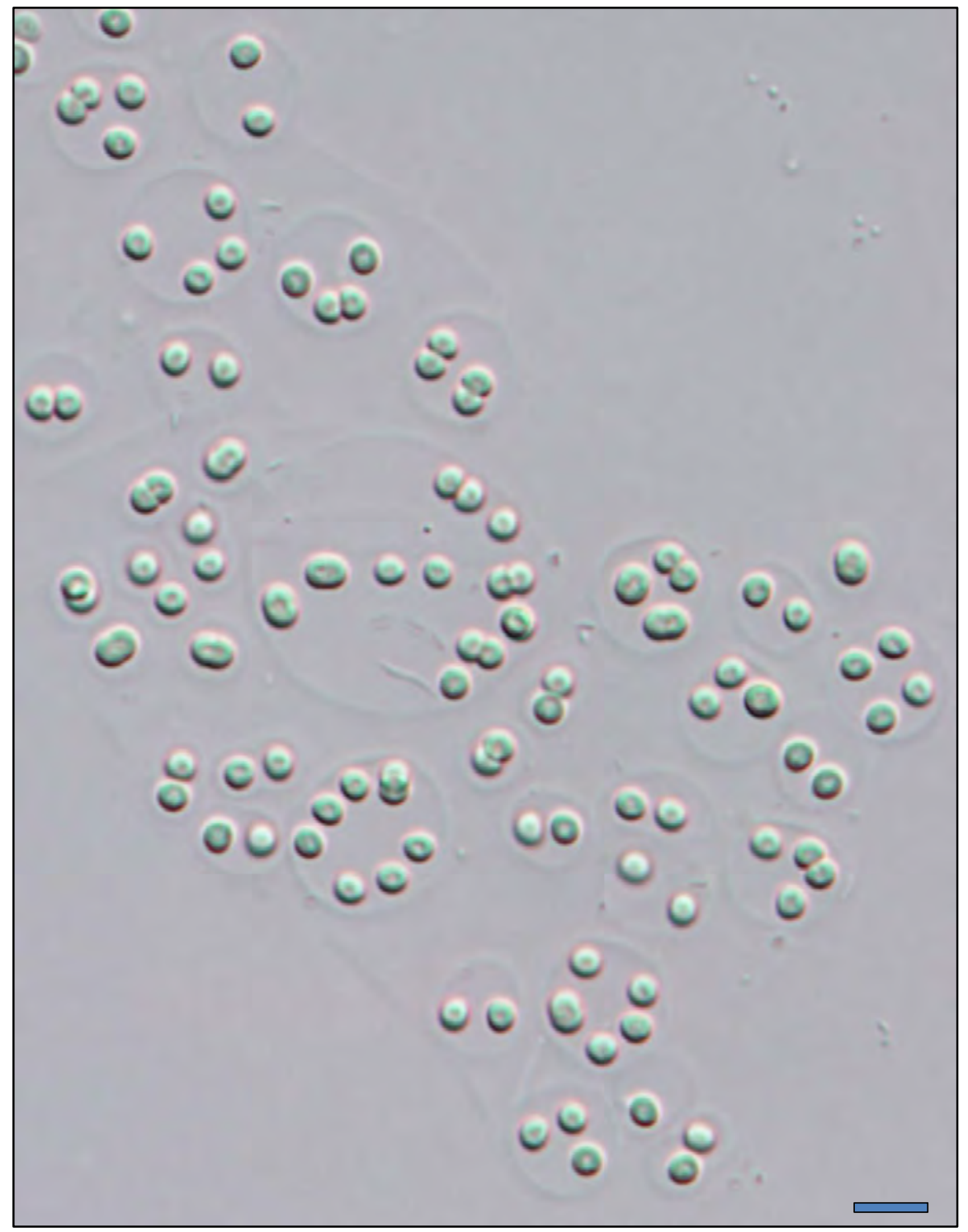

Figure 2. Gloeocapsa punctata Nägeli; bar is $10 \mu \mathrm{m}$ in length (Komárek and Anagnostidis, 1999, fig. 309).

Figure 2 illustrates Gloeocapsa punctata, a colonial form, with individual or small groups of cells in their own mucilaginous envelope. 
Order Chroococcales

Family Microcystaceae

Genus Microcystis
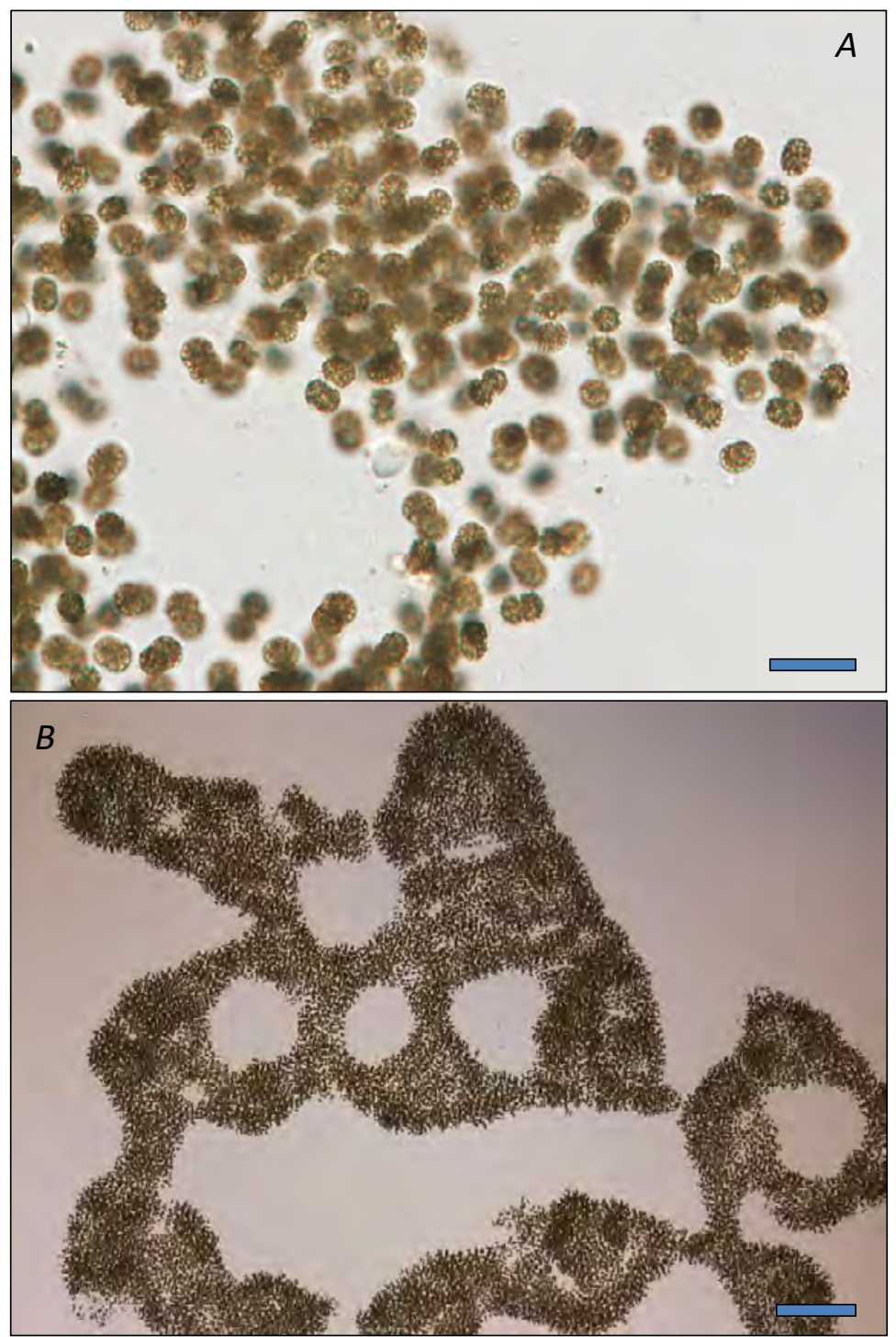

Figure 3. Microcystis aeruginosa (Kützing) Kützing; bar is $20 \mu \mathrm{m}$ in fig. 3A, $100 \mu \mathrm{m}$ in fig. 3B (Komárek and Anagnostidis, 1998, fig. 304).

Figures $3 A$ and $3 B$ illustrate Microcystis aeruginosa, a colonial form, with small cells arranged into colonies. Colonies have large open spaces and are commonly visible without a microscope. 
Order Chroococcales

Family Microcystaceae

Genus Microcystis

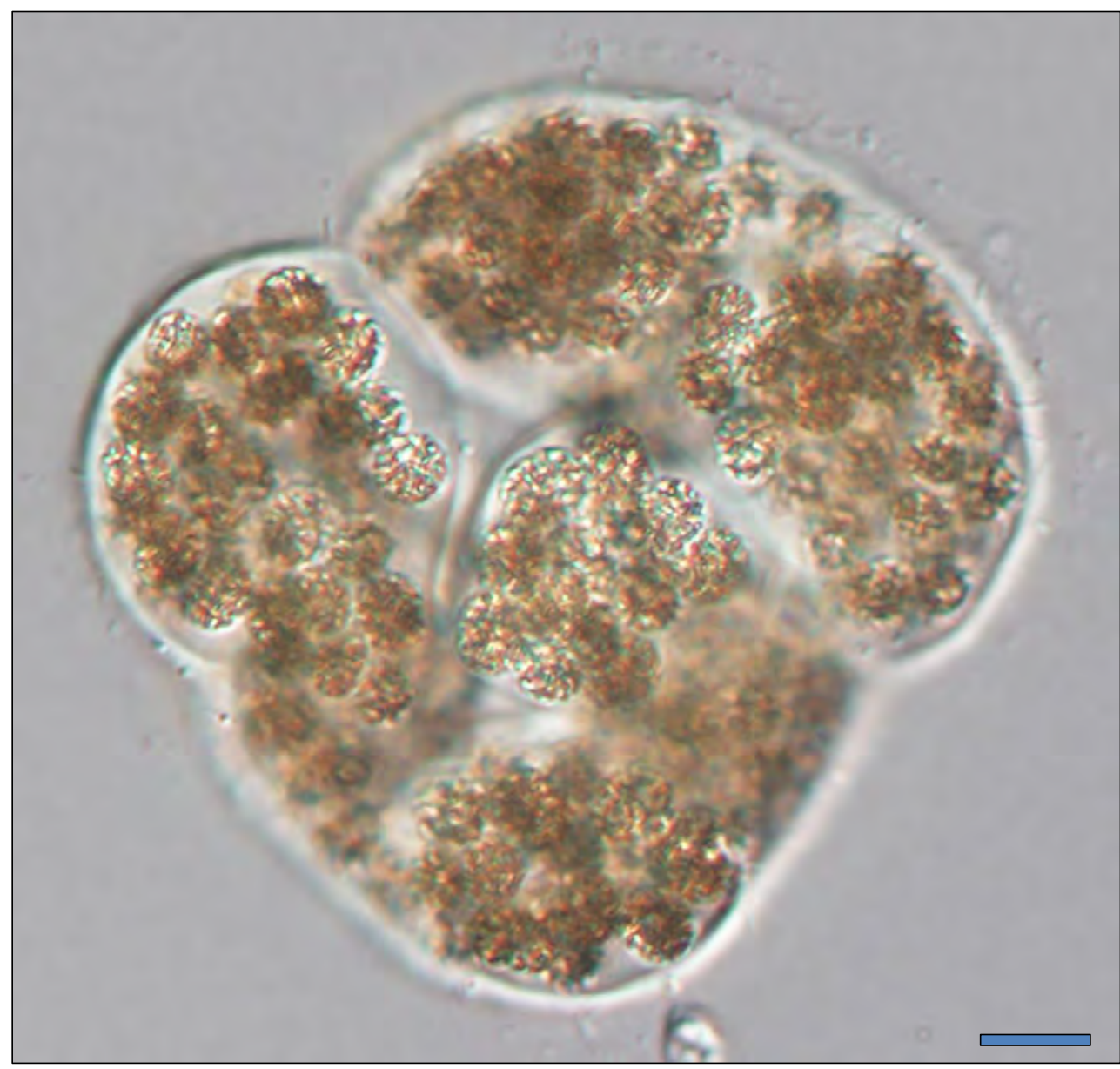

Figure 4. Microcystis wesenbergii (Komárek) Komárek ex Komárek; bar is 10 m (Komárek and Anagnostidis, 1998, fig. 305).

Figure 4 illustrates Microcystis wesenbergii, a colonial form, with small cells arranged into colonies with thick mucilage and often lobed. 


\section{Order Nostocales \\ Family Aphanizomenonaceae \\ Genus Cuspidothrix}

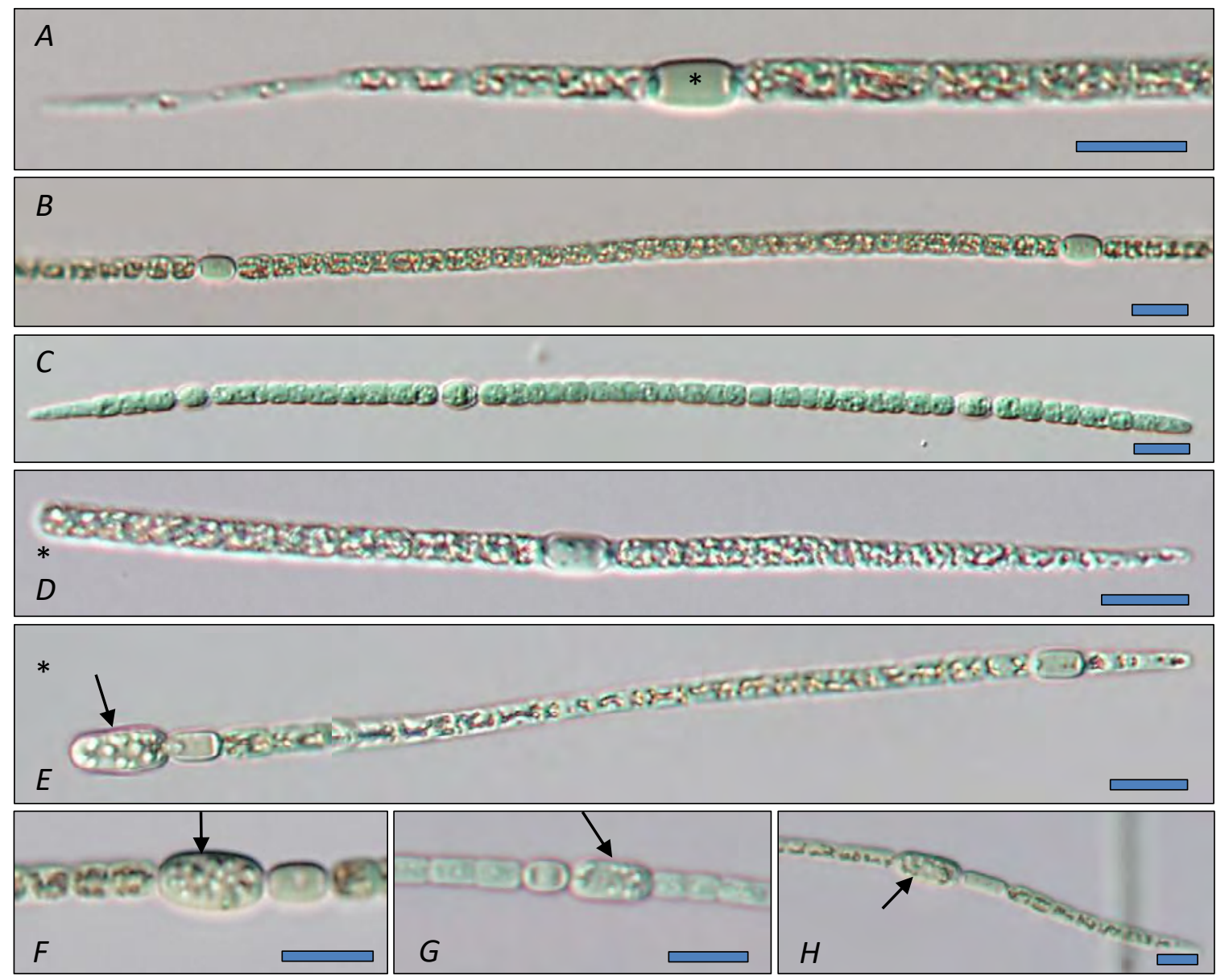

Figure 5. Cuspidothrix tropicalis (Horecká \& Komárek) P. Rajaniemi, J. Komárek, R. Willame, P. Hrouzek, K. Kastovská, L. Hoffmann \& K. Sivonen; bars are 10 m (Komárek, 2013, fig. 828).

Figure $5 A$ has the characteristics of Cuspidothrix issatschenkoi and may be this species. $5 B-4 H$ illustrate Cuspidothrix tropicalis, a filamentous form that has a tapered terminal cell $(5 C-5 E$ and $5 H$ ). Heterocytes are elongated $\left(^{*}\right)$ and akinetes (figs. $5 E-5 H$ ), at arrows, are wider than the vegetative cells of the filament and are adjacent to the heterocytes. The genus Cuspidothrix was separated from Aphanizomenon in Rajaniemi and others, 2005. To the authors' knowledge, this is the first time this organism has been reported in the United States. 


\section{Order Nostocales}

Family Aphanizomenonaceae

Genus Cylindrospermopsis

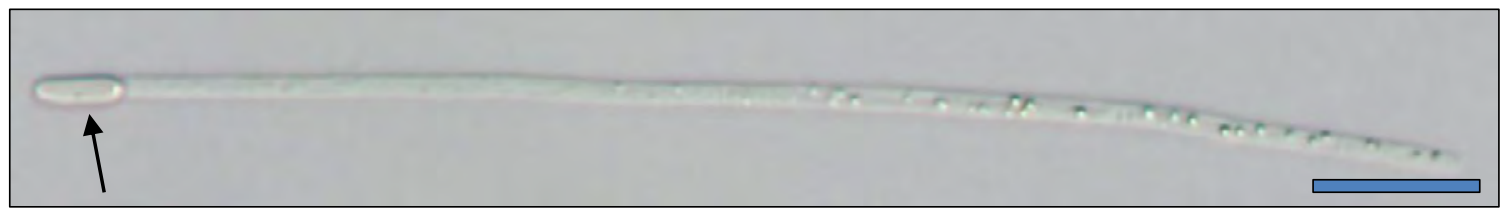

Figure 6. Cylindrospermopsis raciborskii (Woloszynska) Seenayya \& Subba Raju; bar is $20 \mu \mathrm{m}$ (Komárek, 2013, fig. 835).

Figure 6 illustrates Cylindrospermopsis raciborskii, with straight morphology, is a filamentous form that has a characteristic terminal heterocyte (at arrow). 
Order Nostocales

Family Aphanizomenonaceae

Genus Dolichospermum
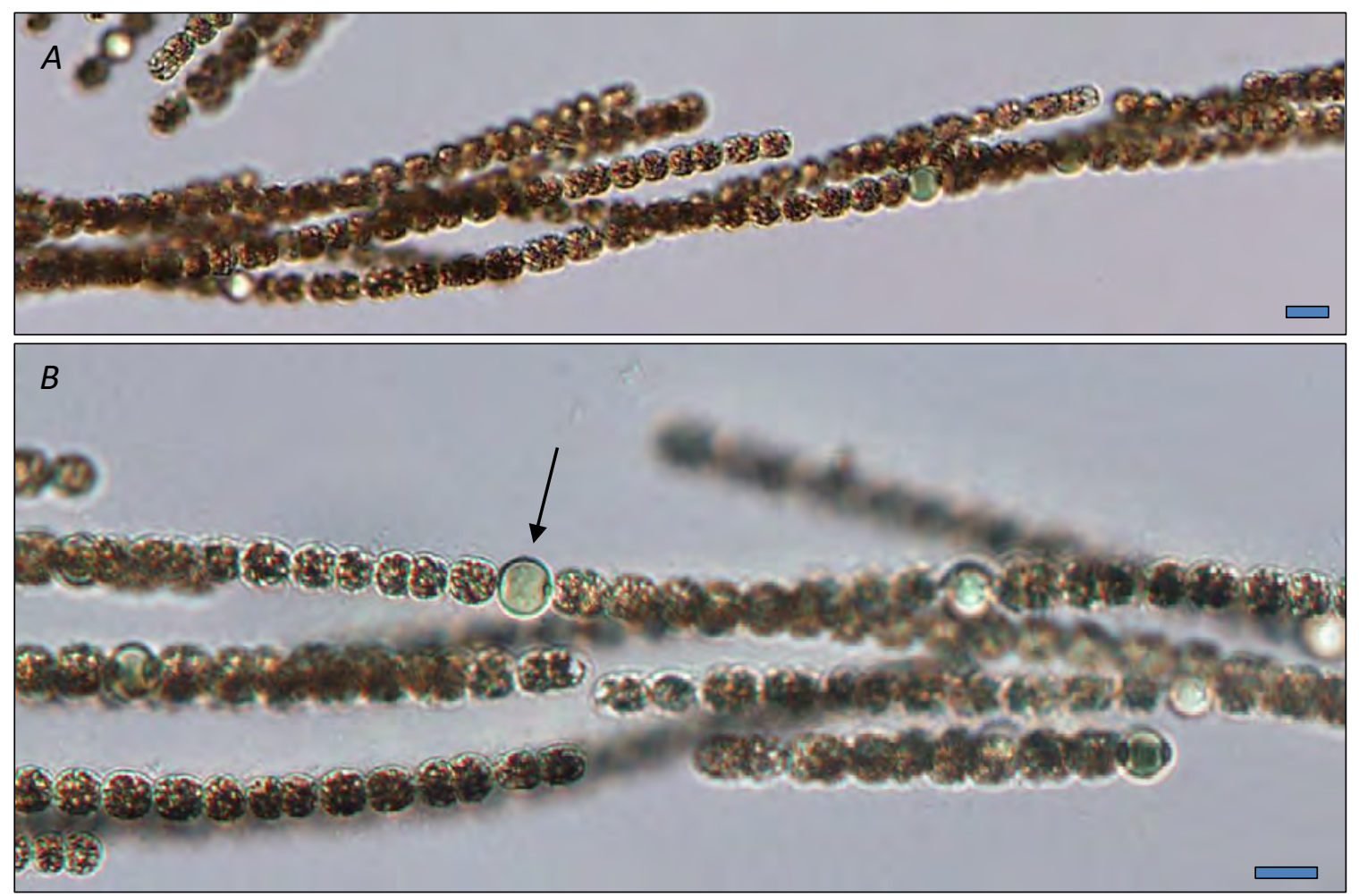

Figure 7. Dolichospermum affine (Lemmermann) Wacklin, L. Hoffmann \& Komárek; bars are $10 \mu \mathrm{m}$ in length (Komárek, 2013, fig. 893, Wacklin and others, 2009).

Figures $7 A$ and $7 B$ illustrate Dolichospermum affine, a filamentous form that has a spherical cells and heterocytes (at arrow). Filaments loosely associated in parallel to form fascicles. The genus that encompassed planktonic Anabaena was changed to Dolichospermum by Wacklin and others, 2009. 


\section{Order Nostocales \\ Family Aphanizomenonaceae \\ Genus Dolichospermum}

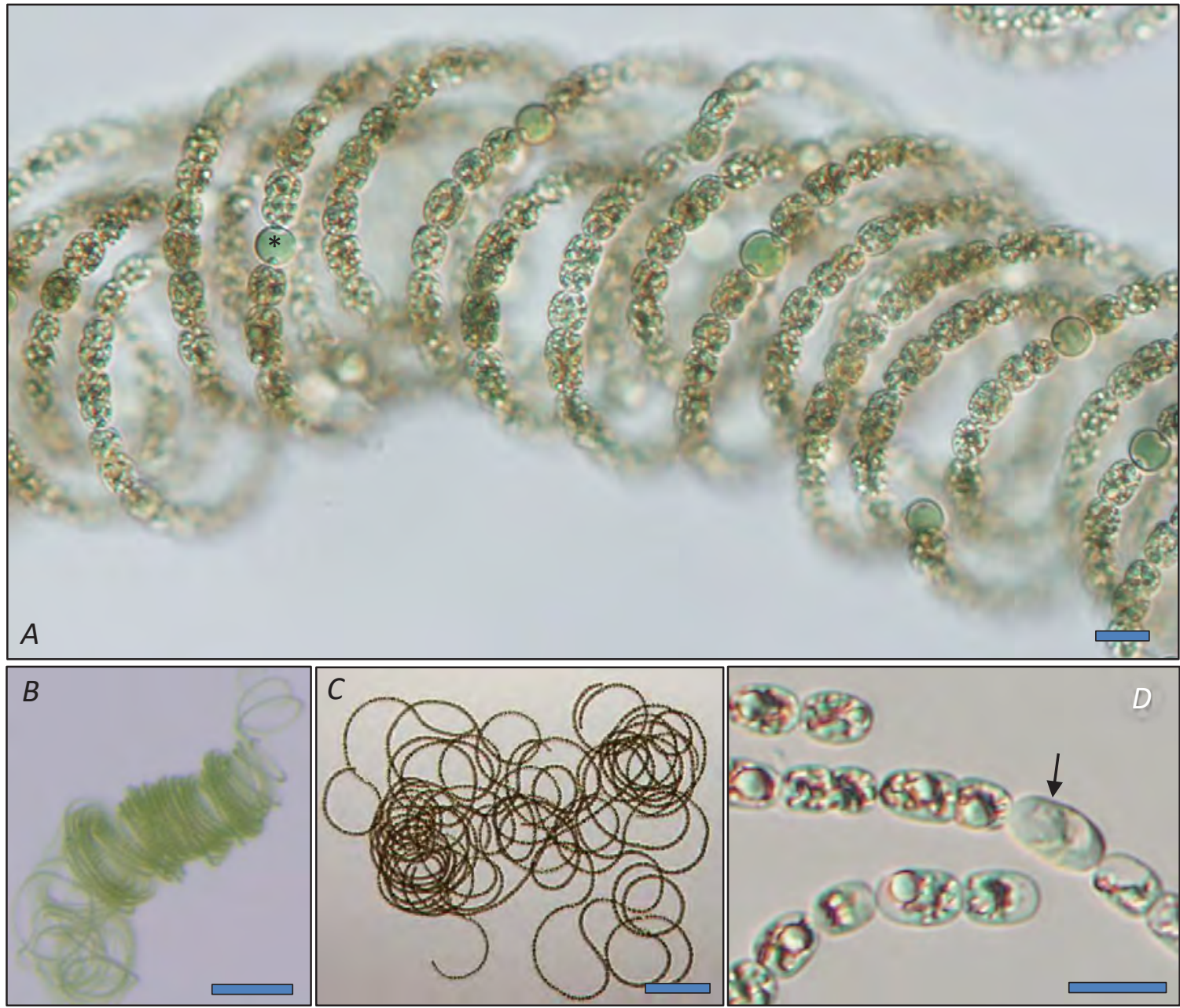

Figure 8. Dolichospermum circinale (Rabenhorst ex Bornet \& Flahault) P. Wacklin, L. Hoffmann \& J. Komárek; bars are $10 \mu \mathrm{m}$ in length in figs. $8 A$ and $8 D$, and $100 \mu \mathrm{m}$ figs. $8 B$ and $8 C$, (Komárek, 2013, fig. 867, Wacklin and others, 2009).

Figures $8 A-8 D$ illustrate Dolichospermum circinale, a filamentous form that coils (figs. $8 A-8 C$ ). Heterocytes are spherical $\left(^{*}\right)$ and akinetes (fig. $8 D$ ) at arrow, is wider than the filament and larger than the vegetative cells. Filaments loosely associated in parallel to form fascicles. The genus that encompassed planktonic Anabaena was changed to Dolichospermum by Wacklin and others, 2009. 


\section{Order Nostocales}

Family Aphanizomenonaceae

Genus Dolichospermum

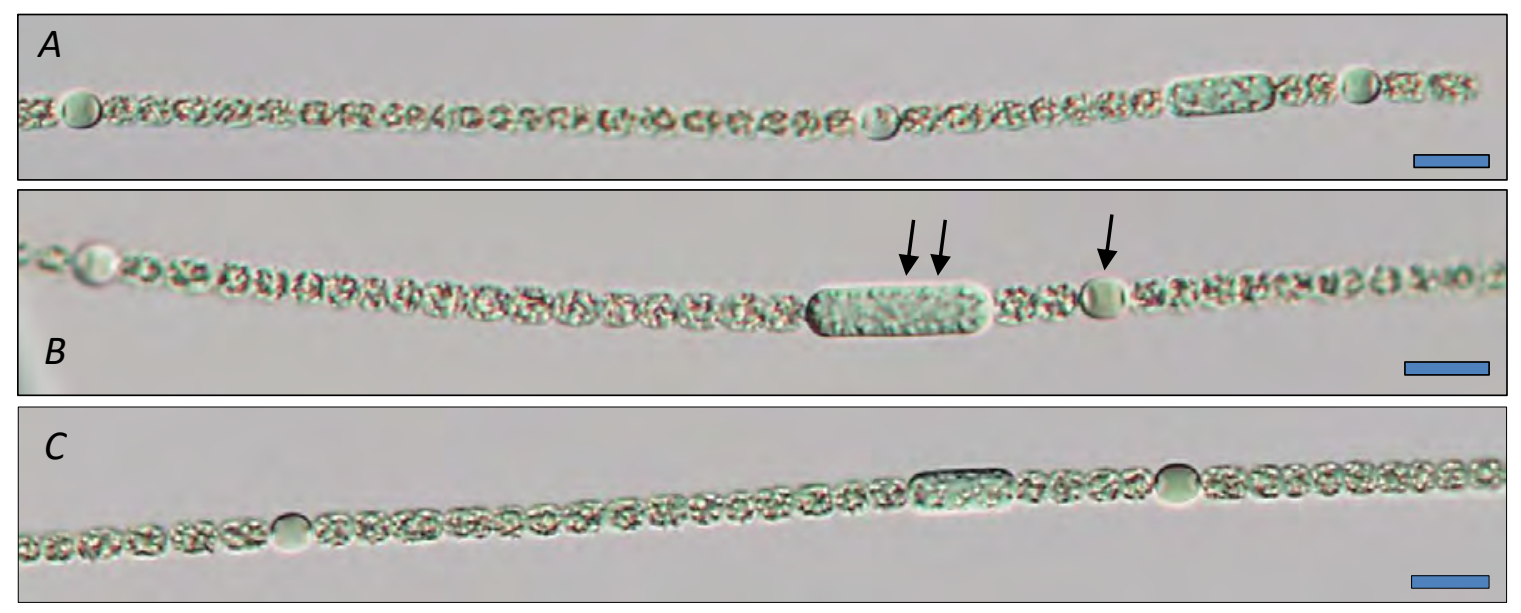

Figure 9. Dolichospermum heterosporum (Nygaard) P. Wacklin, L. Hoffmann \& J. Komárek; bars are $10 \mu \mathrm{m}$ (Komárek, 2013, fig. 882).

Figures $9 A-9 C$ illustrate Dolichospermum heterosporum, a filamentous form that is mostly straight to slightly curved (figs. 9A-9B) and is not tapered (fig. 9A). Heterocytes are spherical (single arrow) and akinetes are elongated (at double arrow), wider than the filament and within 2-4 cells of the heterocyte. Filaments loosely associated in parallel to form fascicles. The genus that encompassed planktonic Anabaena was changed to Dolichospermum by Wacklin and others, 2009. 


\section{Order Nostocales \\ Family Aphanizomenonaceae \\ Genus Dolichospermum}

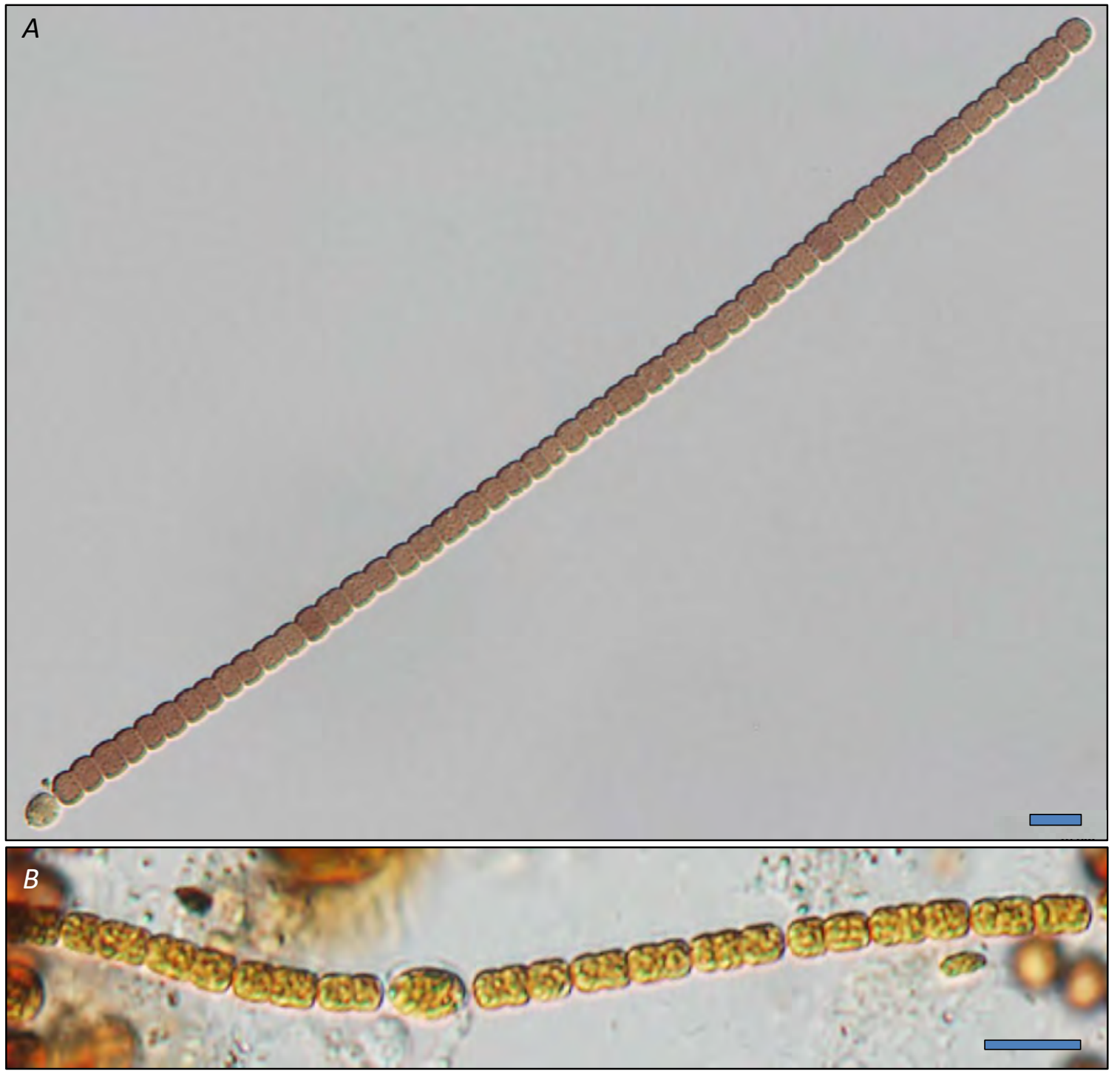

Figure 10. Dolichospermum sp. (Ralfs ex Bornet \& Flahault) P. Wacklin, L. Hoffmann \& J. Komárek; bars are $10 \mu \mathrm{m}$ (Wacklin and others, 2009).

Figures $10 A$ and $10 B$ illustrate Dolichospermum sp. that can not be identified to the species level because morphological characteristics are lacking. The genus that encompassed planktonic Anabaena was changed to Dolichospermum by Wacklin and others, 2009. 


\section{Order Nostocales \\ Family Fortiaceae \\ Genus Fortiea}

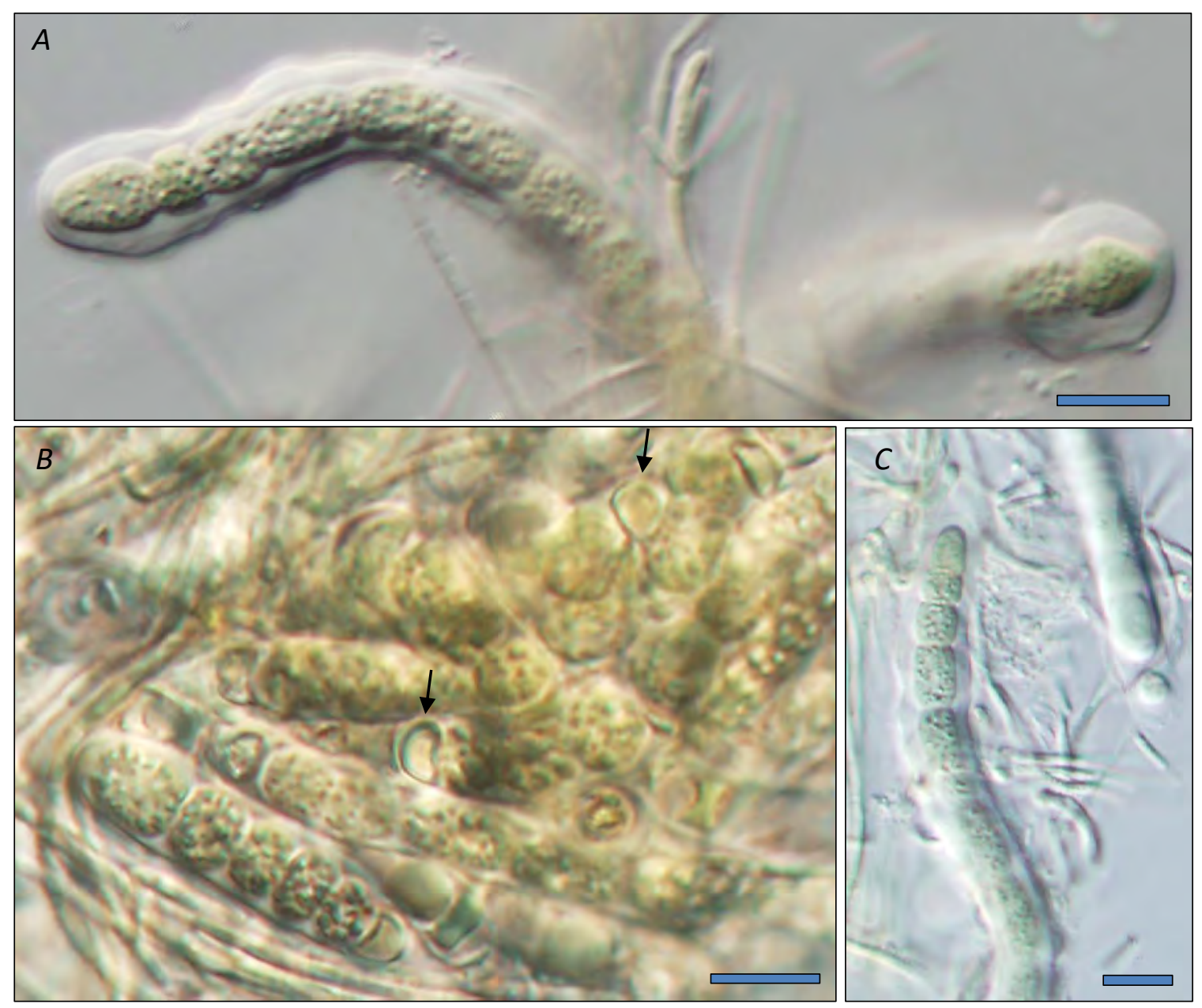

Figure 11. Fortiea monilispora Komárek; bars are $10 \mu \mathrm{m}$ in length (Komárek, 2013, fig. 475).

Figures $11 A-11 C$ illustrate Fortiea monilispora, a filamentous form that has terminal cells that are conical and curved filaments (figs. $11 A-11 C$ ). Mucilage envelopes each filament. Heterocytes are hemispherical and may be flattened (fig. 11B at arrows). 


\section{Order Nostocales}

Family Hapalosiphonaceae

Genus Hapalosiphon

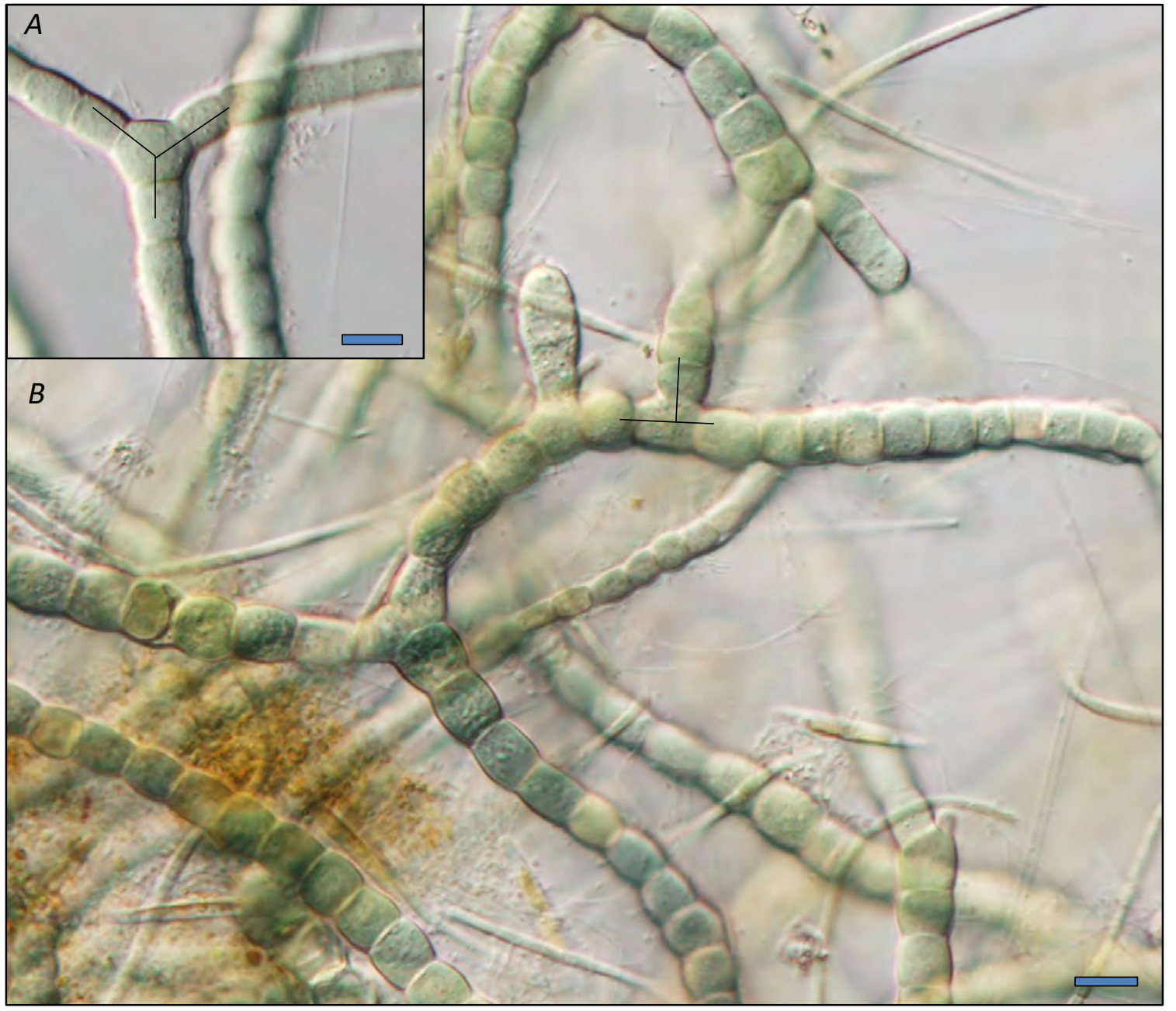

Figure 12. Hapalosiphon sp. Nägeli ex É. Bornet \& C. Flahault; bars are $10 \mu \mathrm{m}$ in length (Komárek, 2013). See figure 13 for full description of what is depicted in these images. 


\section{Order Nostocales \\ Family Hapalosiphonaceae \\ Genus Hapalosiphon}
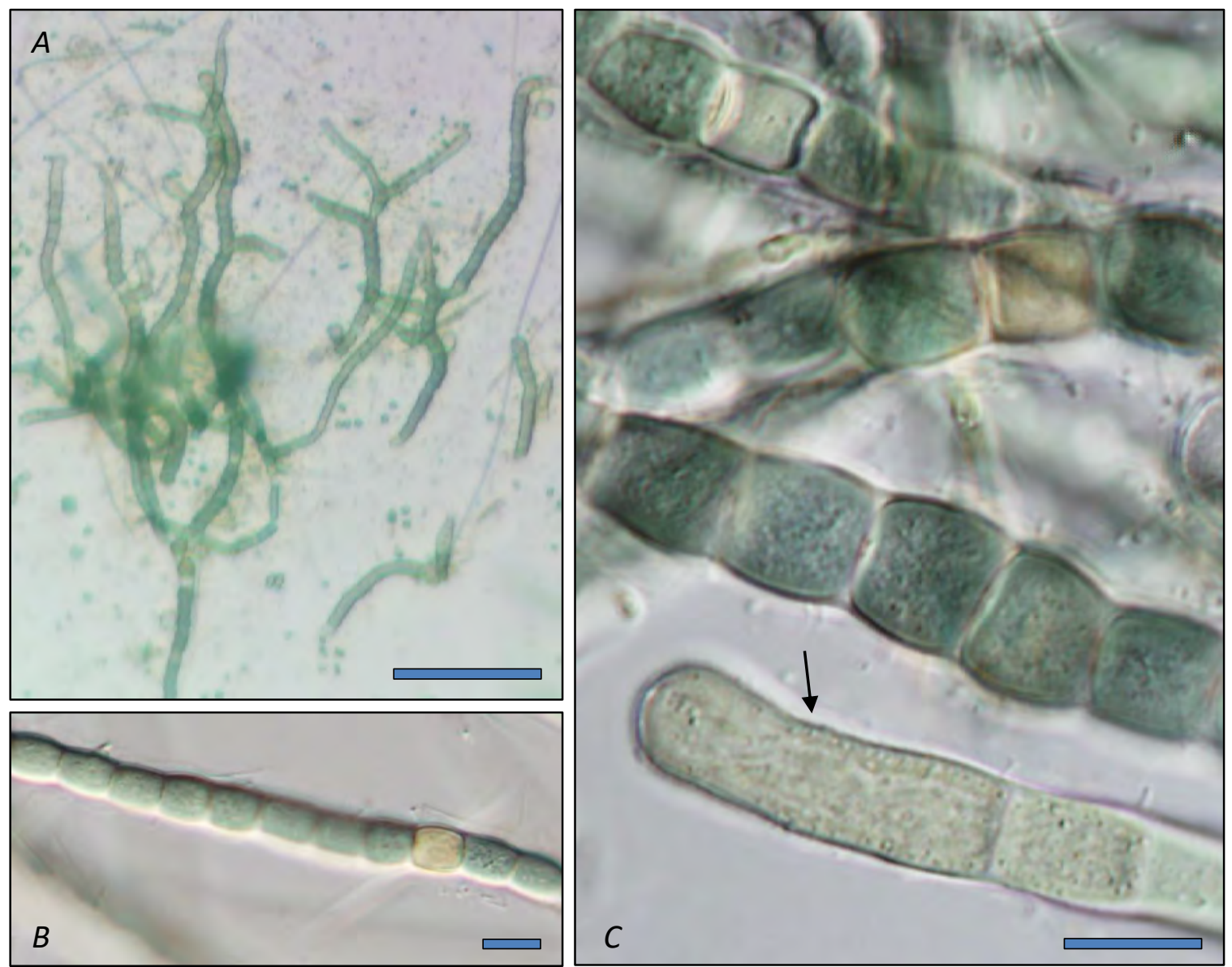

$B$

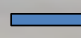

Figure 13. Hapalosiphon sp. Nägeli ex É. Bornet \& C. Flahault; bar length in fig. $13 A$ is $100 \mu \mathrm{m}$; bar length in figs. $13 B$ and $13 C$ is $10 \mu \mathrm{m}$ (Komárek, 2013).

Figures 12-13 illustrate Hapalosiphon sp., a true branching filamentous form that has an elongated terminal cell (fig. 13C). The true branching illustrated in fig. 12A has the typical " $Y$ " pattern characteristic in this genus. Fig. 12B shows that the branches can also form perpendicular to the main filament. Overall, the filaments can form visible tuffs that branch (fig. $13 A$ ) and heterocytes are intercalary (fig. 13B). The elongated terminal cell (fig. 13C, at arrow) is not characteristic of this genus, which may indicate that this is a new species. 
Order Nostocales

Family Nostocaceae

Genus Anabaena

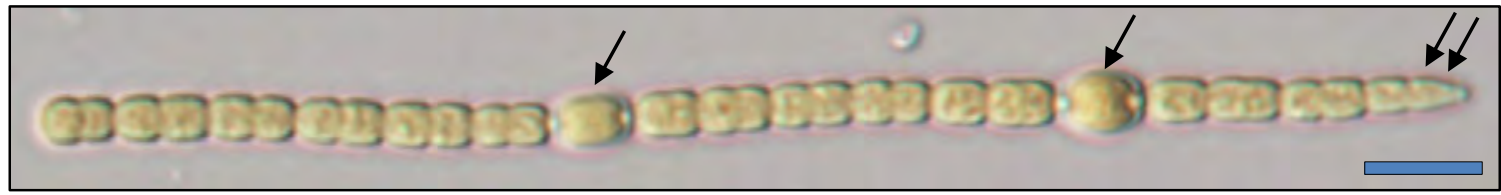

Figure 14. Anabaena mediocris N. L. Gardner; bar is $10 \mu \mathrm{m}$ in length (Komárek, 2013, fig. 1044).

Figure 14 illustrates Anabaena mediocris, a filamentous form that is mostly straight to slightly curved and is tapered with a conical terminal cell (double arrow). Heterocytes, which differentiate from vegetative cells, are elongated (at arrows), and are wider than the filament. Note that the different sizes of the two heterocytes in this image, with the smaller one (left single arrow) being formed more recently that the larger heterocyte (right single arrow). Aerotopes are absent. 


\section{Order Nostocales \\ Family Nostocaceae \\ Genus Macrospermum}

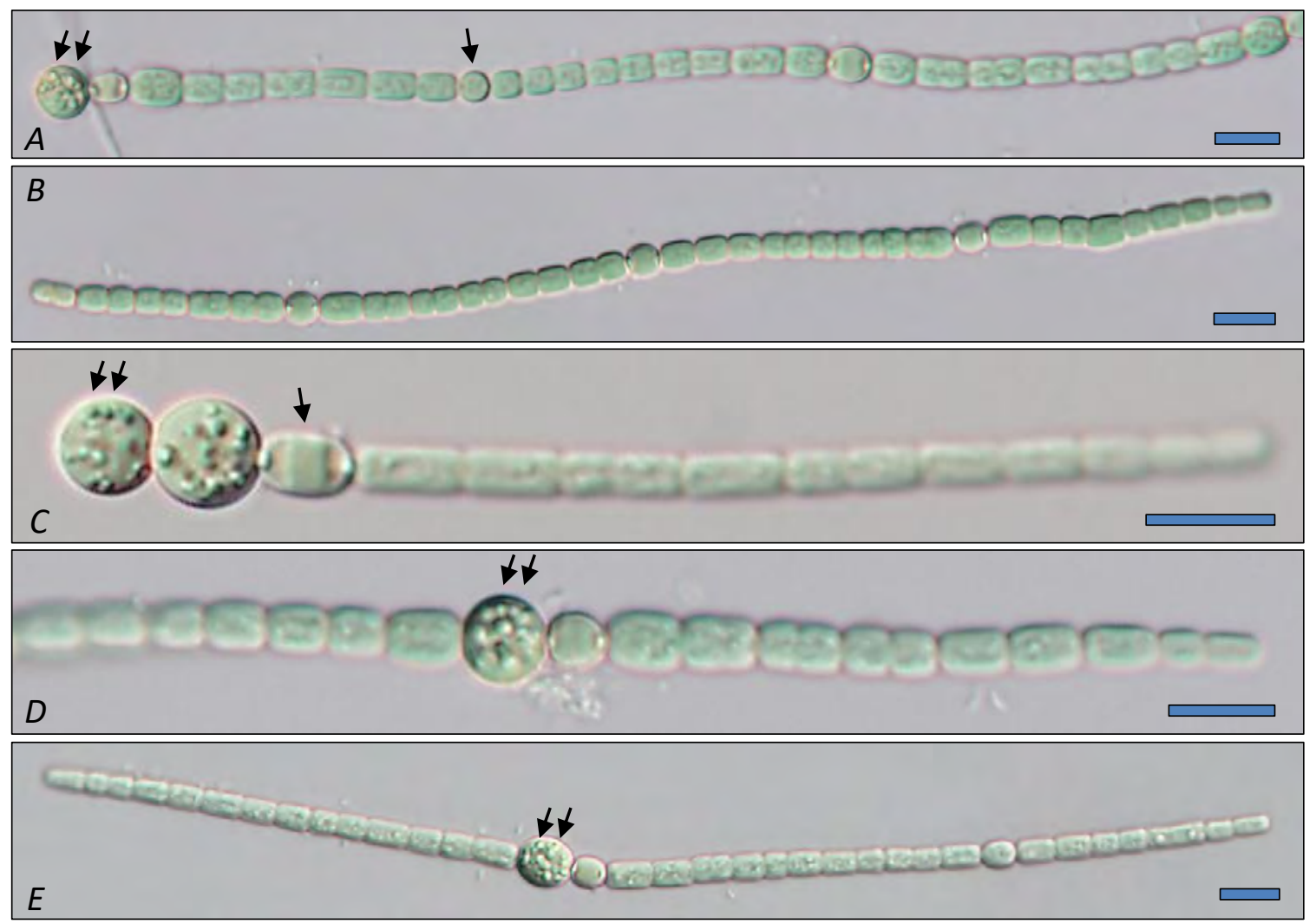

Figure 15. Macrospermum volzii (Lemmermann) Komárek; bars are $10 \mu \mathrm{m}$ in length (Komárek, 2013, fig. 1112).

Figures 15A-15E illustrate Macrospermum volzii, a filamentous form that is mostly straight to slightly curved (figs. 15B, 15C, 15D). Filaments are tapered (figs. 15C, fig.15D and fig.15F). Heterocytes are spherical when young (fig. 15A at arrow) and elongate as they mature (fig. 15C at arrow). Akinetes are spherical, enlarged and adjacent to the heterocytes, either intercalary (figs. $15 D$ and $15 E$, double arrow) or in the terminal position (figs. $15 A$ and $15 C$, double arrow). 


\section{Order Nostocales \\ Family Nostocaceae \\ Genus Nostoc}
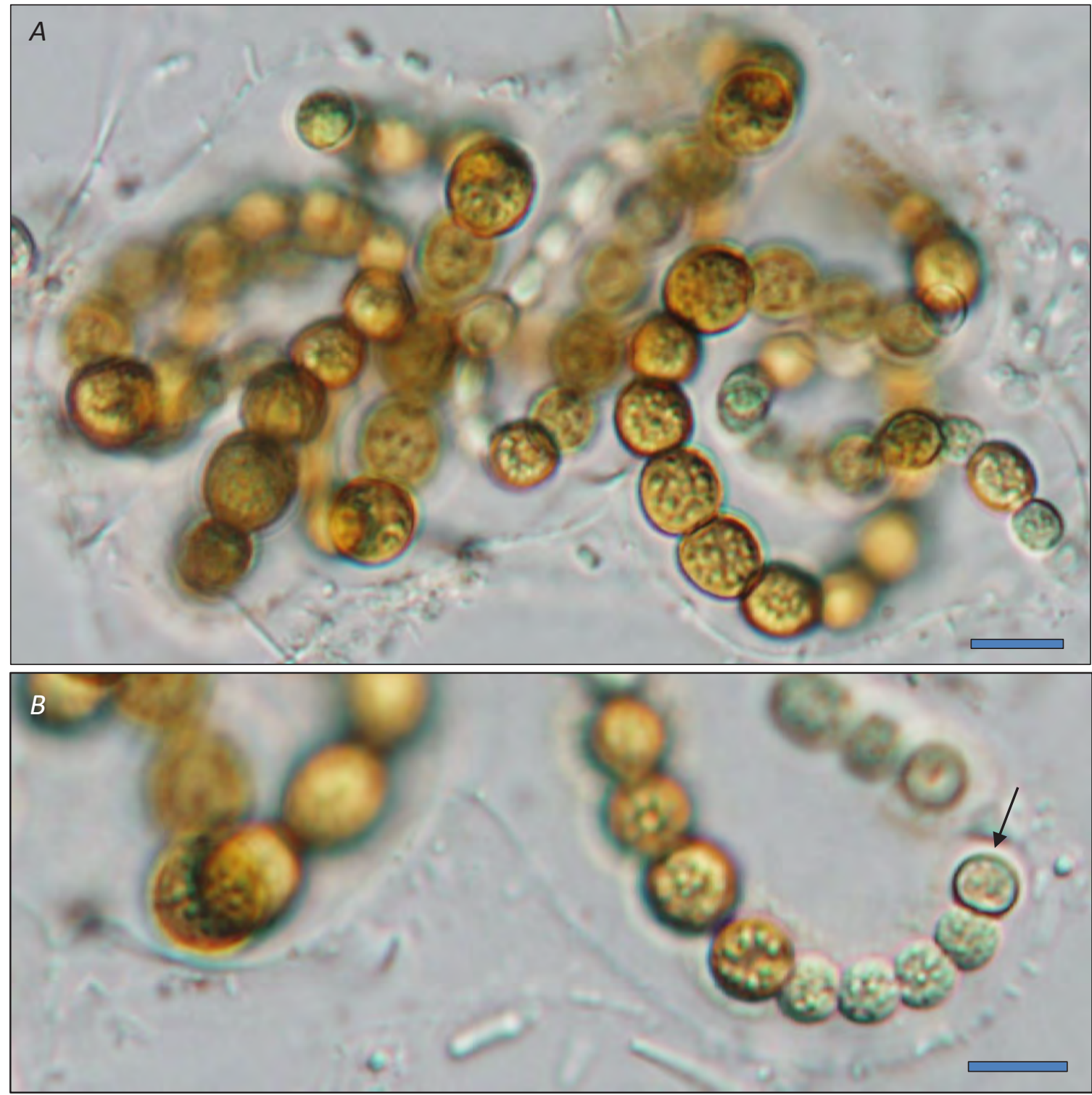

Figure 16. Nostoc sp. Vaucher ex Bornet \& Flahault; bars are $10 \mu \mathrm{m}$ in length (Komárek, 2013).

Figures $16 \mathrm{~A}$ and $16 \mathrm{~B}$ illustrates Nostoc sp., a filamentous form that is mostly coiled and an abundance of mucilage. Cells are spherical and deeply constricted between cells. Heterocytes spherical and the same size as other cells in the filament (at arrow). Aerotopes are absent. 
Order Oscillatoriales

Family Microcoleaceae

Genus Planktothrix

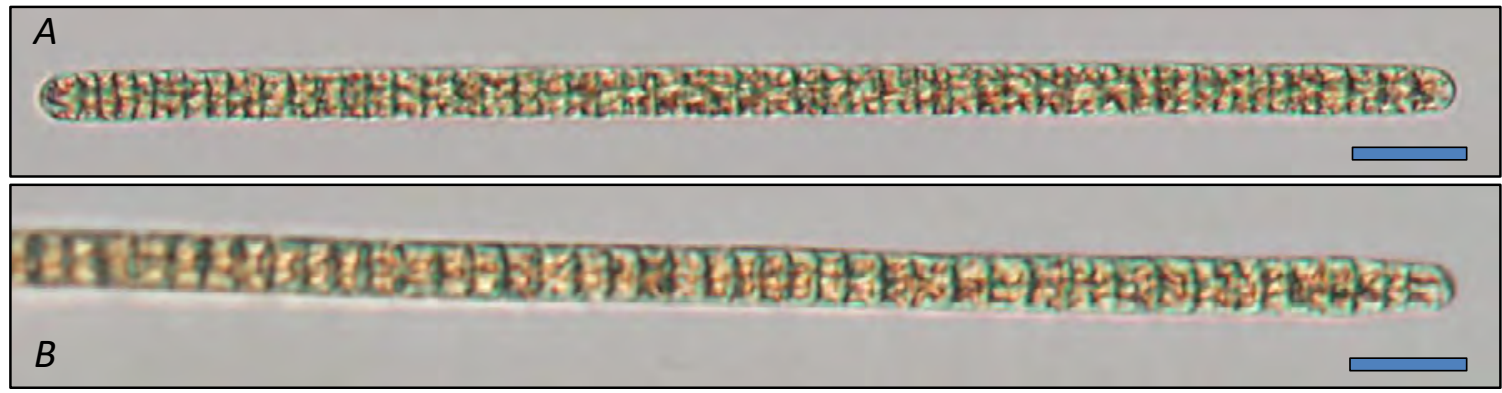

Figure 17. Planktothrix suspensa (Pringsheim) Anagnostidis \& Komárek; bars are $20 \mu \mathrm{m}$ in length (Komárek and Anagnostidis, 2005, fig. 498).

Figures $17 A$ and $17 B$ illustrate Planktothrix suspensa, a filamentous form that is mostly straight. Cells are shorter than they are wide, and there is no constriction between cells. Terminal cell is broadly rounded and in some filaments, slightly tapered. Aerotopes are abundant. 
Order Synechococcales

Family Coelosphaeriaceae

Genus Coelomoron
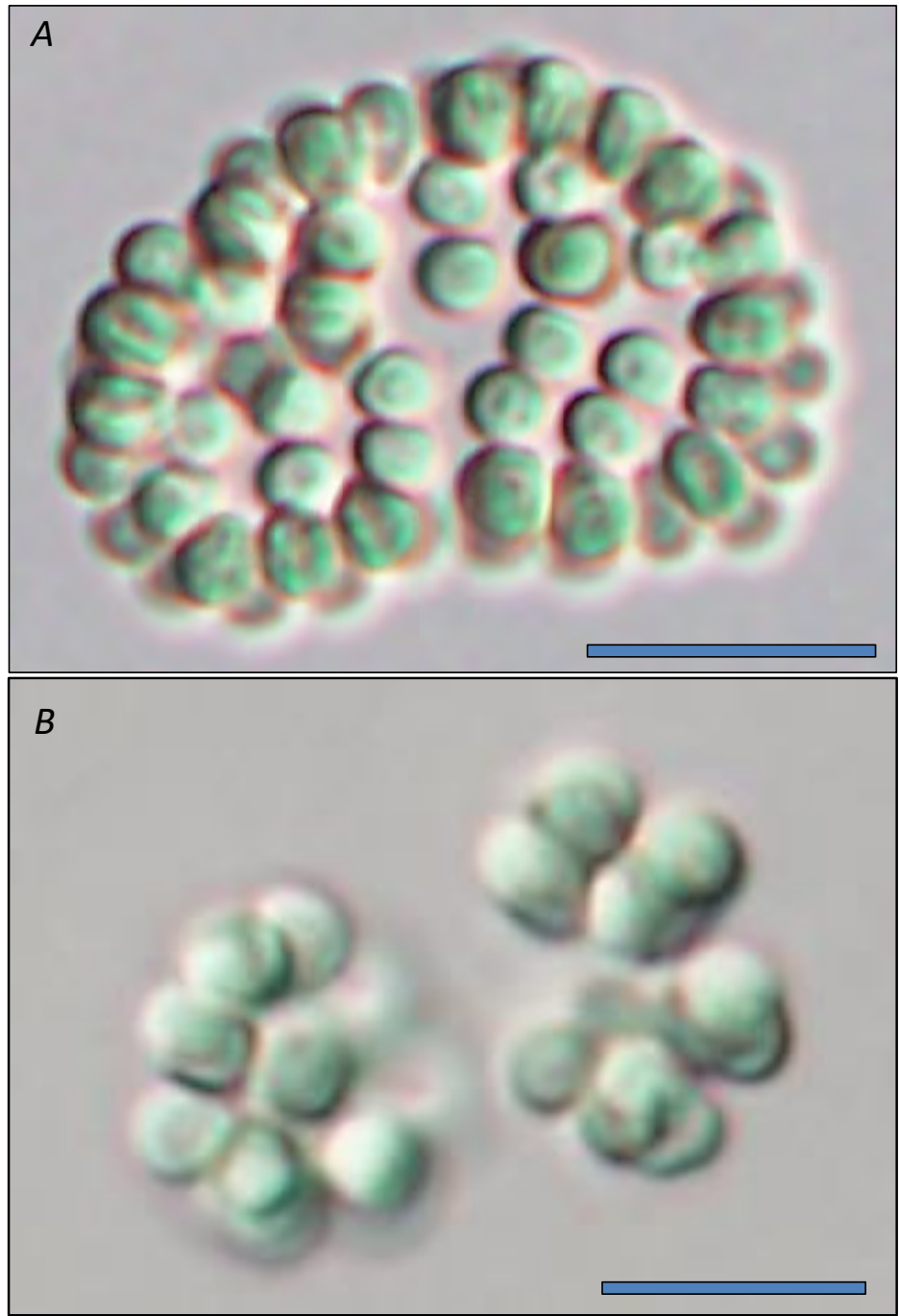

Figure 18. Coelomoron pusillum (Van Goor) Komárek; bars are $10 \mu \mathrm{m}$ in length (Komárek and Anagnostidis, 1998, fig. 262).

Figures $18 \mathrm{~A}$ and $18 \mathrm{~B}$ illustrate Coelomoron pusillum, a colonial form, with small cells arranged into colonies. Young colony cells are cells more tightly packed (fig. 18B) compared to older colonies (fig. 18A). 
Order Synechococcales

Family Leptolyngbyaceae

Genus Planktolyngbya

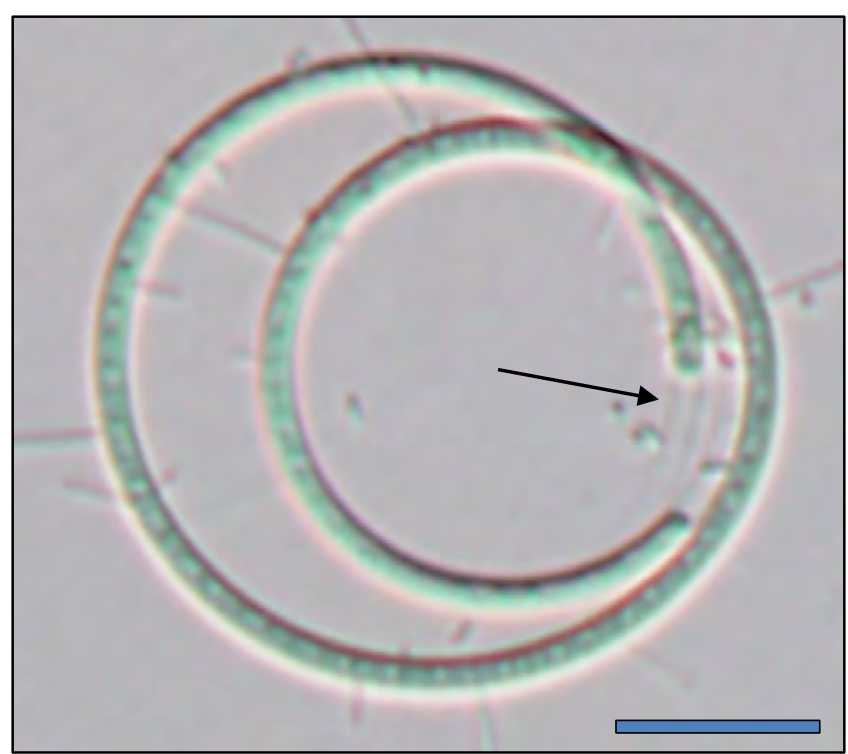

Figure 19. Planktolyngbya contorta (Lemmermann)

Anagnostidis and Komárek; bar is $10 \mu \mathrm{m}$

(Komárek and Anagnostidis, 2005, fig. 196).

Figure 19 illustrates Planktolyngbya contorta, a thin filamentous form that is coiled. Sheath can be observed (at arrow). 
Order Synechococcales

Family Leptolyngbyaceae

Genus Planktolyngbya

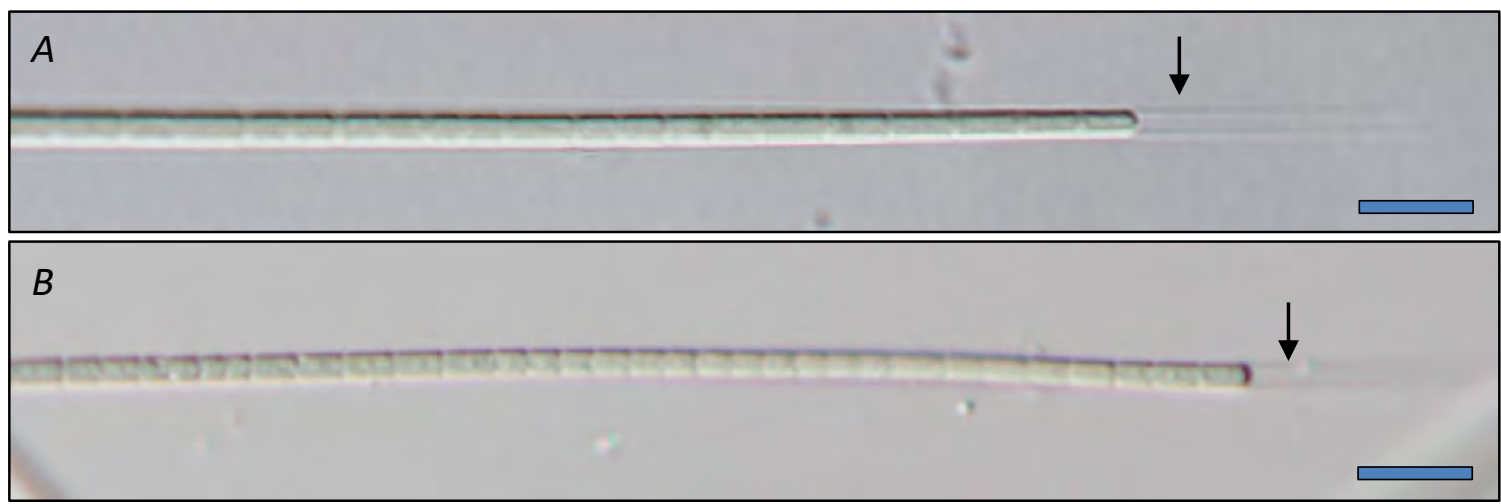

Figure 20. Planktolyngbya limnetica (Lemmermann) Komárková-Legnerová and Cronberg Komárková-Legnerová, J. \& Cronberg, G.; bars are $10 \mu \mathrm{m}$ in length (Komárek and Anagnostidis, 2005, fig. 193).

Figures $20 \mathrm{~A}$ and $20 \mathrm{~B}$ illustrate Planktolyngbya limnetica, a filamentous form that is straight. Sheath can be observed (at arrows). 
Order Synechococcales

Family Merismopediaceae

Genus Aphanocapsa

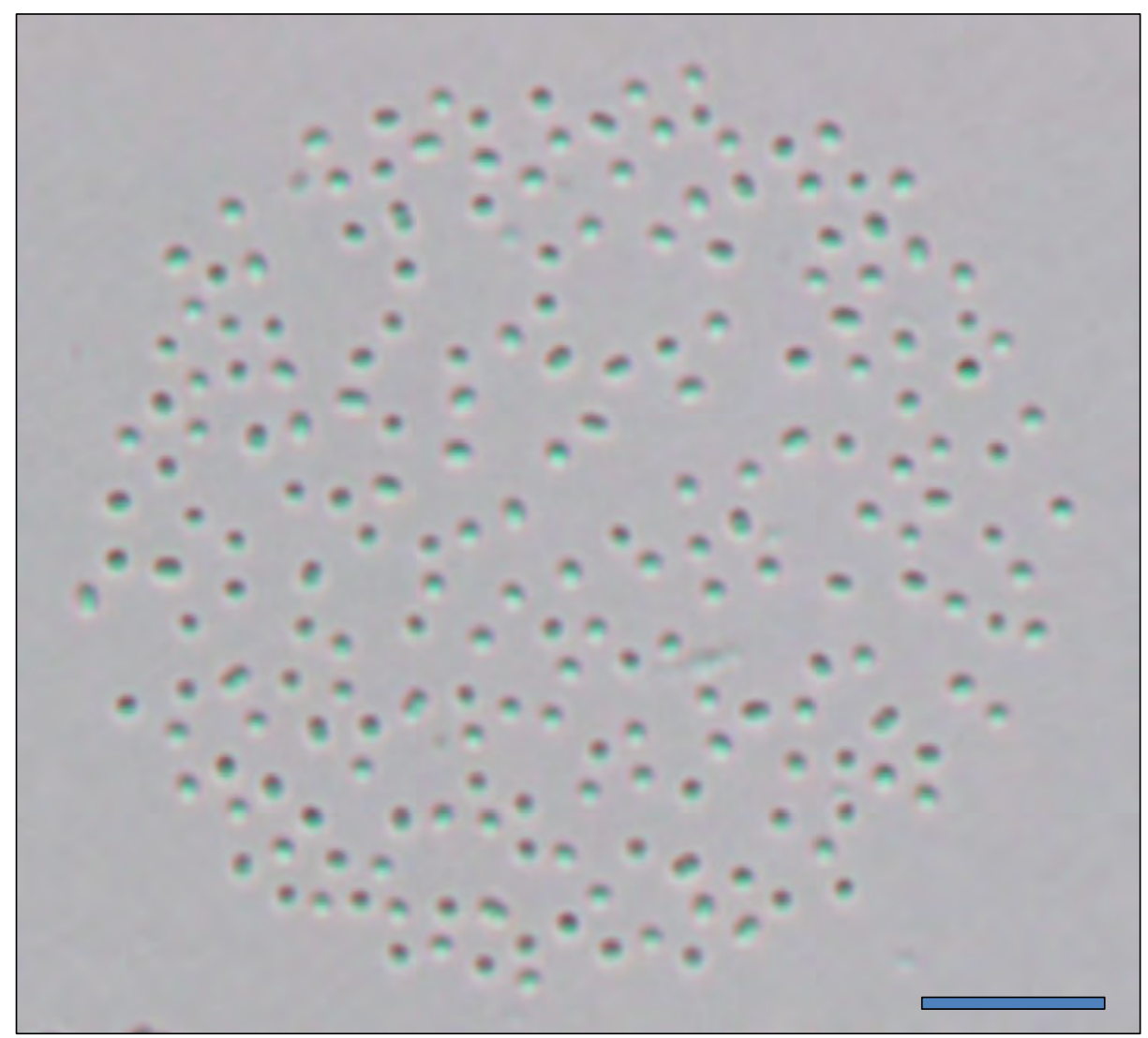

Figure 21. Aphanocapsa delicatissima West and G. S. West; bar is $10 \mu \mathrm{m}$ in length (Komárek and Anagnostidis, 1998, fig. 171).

Figure 21 illustrates Aphanocapsa delicatissima, a colonial form, with very small spherical cells, under $1 \mu \mathrm{m}$ in diameter, loosely packed into a colony. Cells appear elongated before cell division. 
Order Synechococcales

Family Merismopediaceae

Genus Aphanocapsa

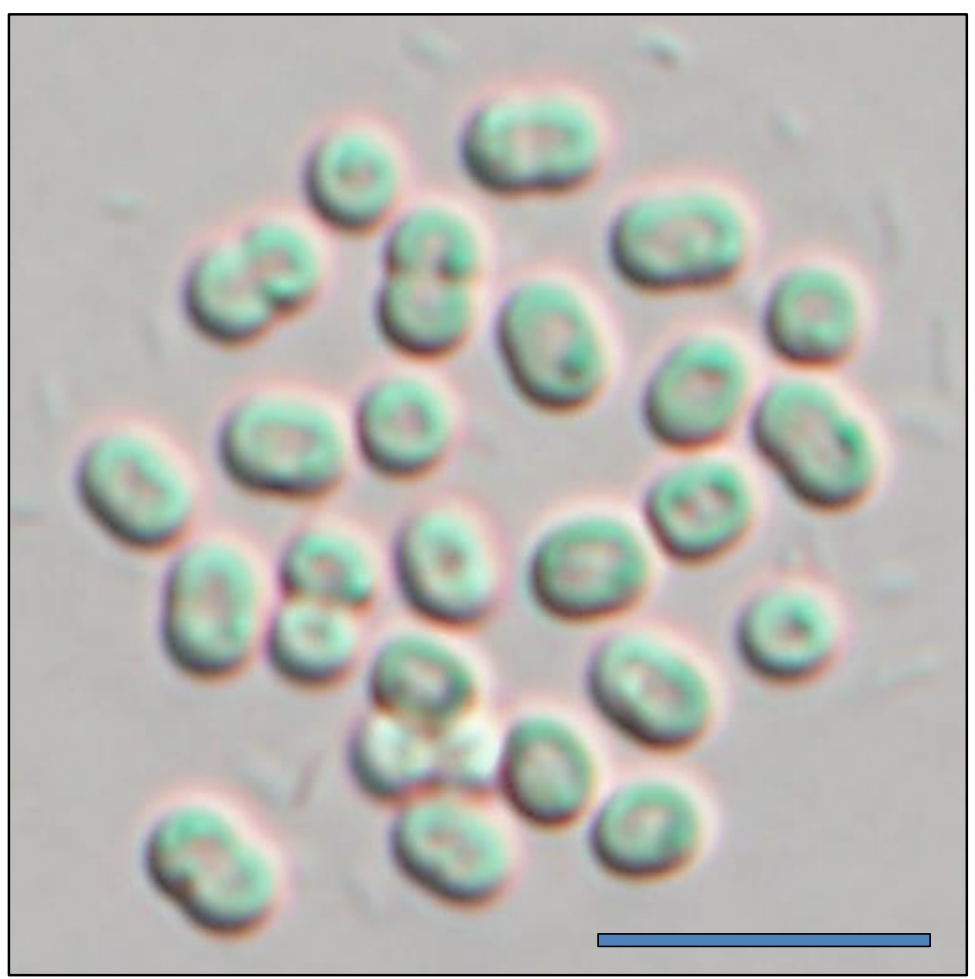

Figure 22. Aphanocapsa cf. planctonica (G. M. Smith); bar is $10 \mu \mathrm{m}$ in length (Komárek and Anagnostidis, 1999, fig. 184).

Figure 22 illustrates Aphanocapsa cf. planctonica, a colonial form, with small spherical cells, 2.75 $\mu \mathrm{m}$ in diameter, packed tightly into a colony. Cells appear elongated before cell division. 


\section{Order Synechococcales \\ Family Merismopediaceae \\ Genus Aphanocapsa}
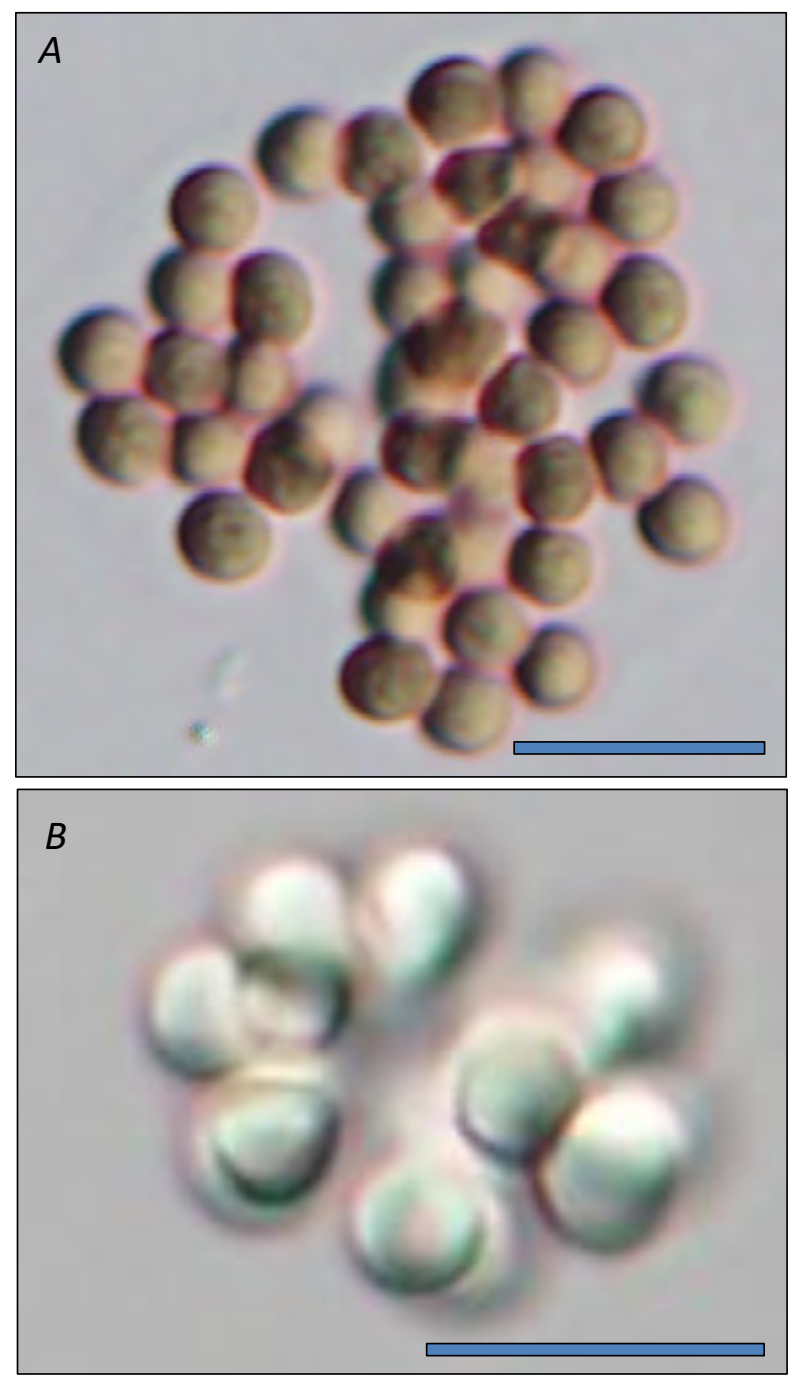

Figure 23. Aphanocapsa grevillei (Berkeley)

Rabenhorst; bars are $10 \mu \mathrm{m}$ in length (Komárek and Anagnostidis, 1998, fig. 194).

Figures $23 A$ and $23 B$ illustrate Aphanocapsa grevillei, a colonial form, with spherical cells, $3.5 \mu \mathrm{m}$ in diameter, packed tightly into a colony. Fig. 23A was preserved in Lugol's iodine (the only image in this document in which a preserved sample was used). 
Order Synechococcales

Family Merismopediaceae

Genus Merismopedia

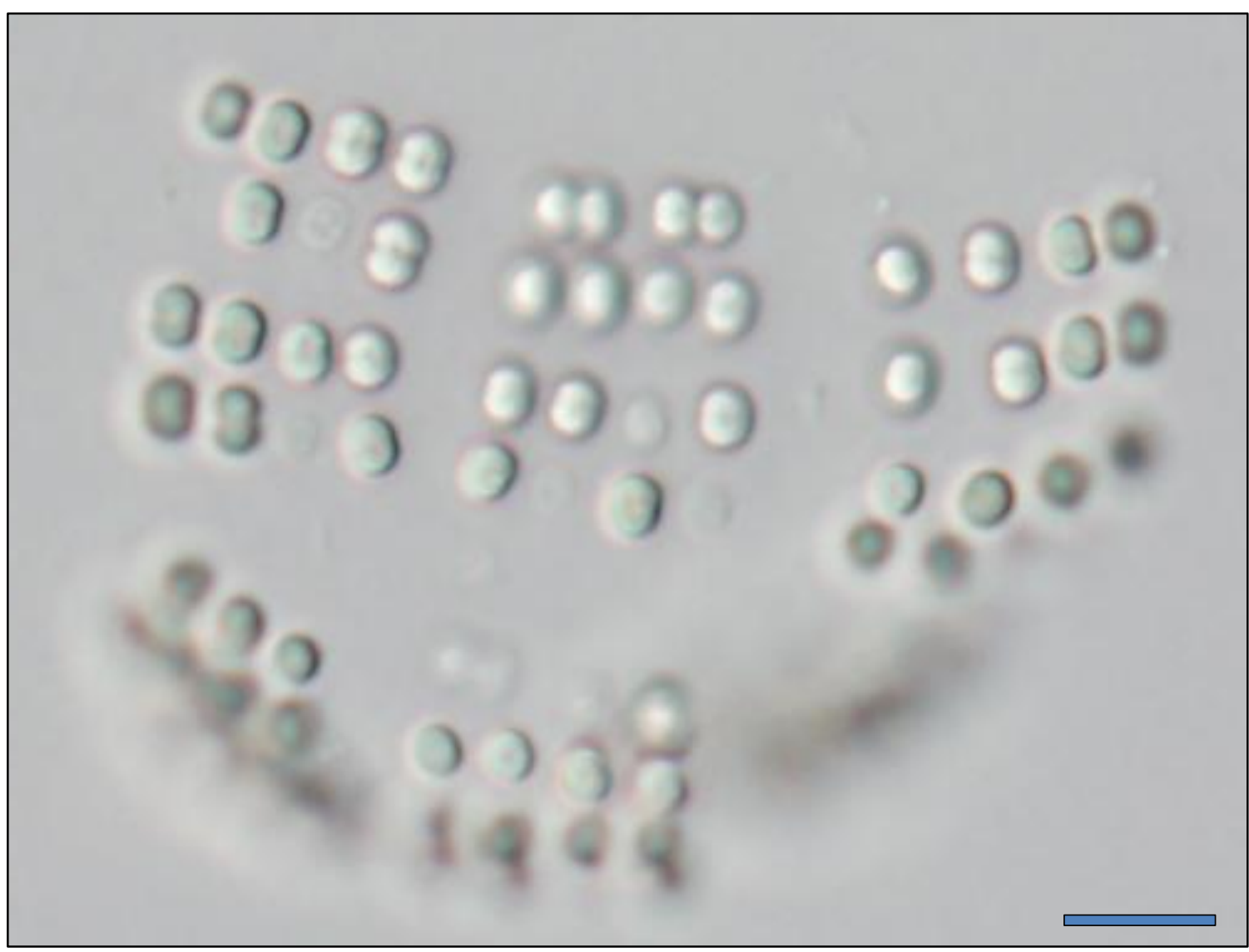

Figure 24. Merismopedia punctata Meyen; bar is $10 \mu \mathrm{m}$ in length (Komárek and Anagnostidis, 1999, fig. 222).

Figure 24 illustrates Merismopedia punctata, a colonial form, with small hemispheric and spherical cells, spaced evenly and regularly from one another, forming a flat sheet of cells. Cells appear elongated before cell division. 
Order Synechococcales

Family Pseudanabaenaceae

Genus Limnothrix

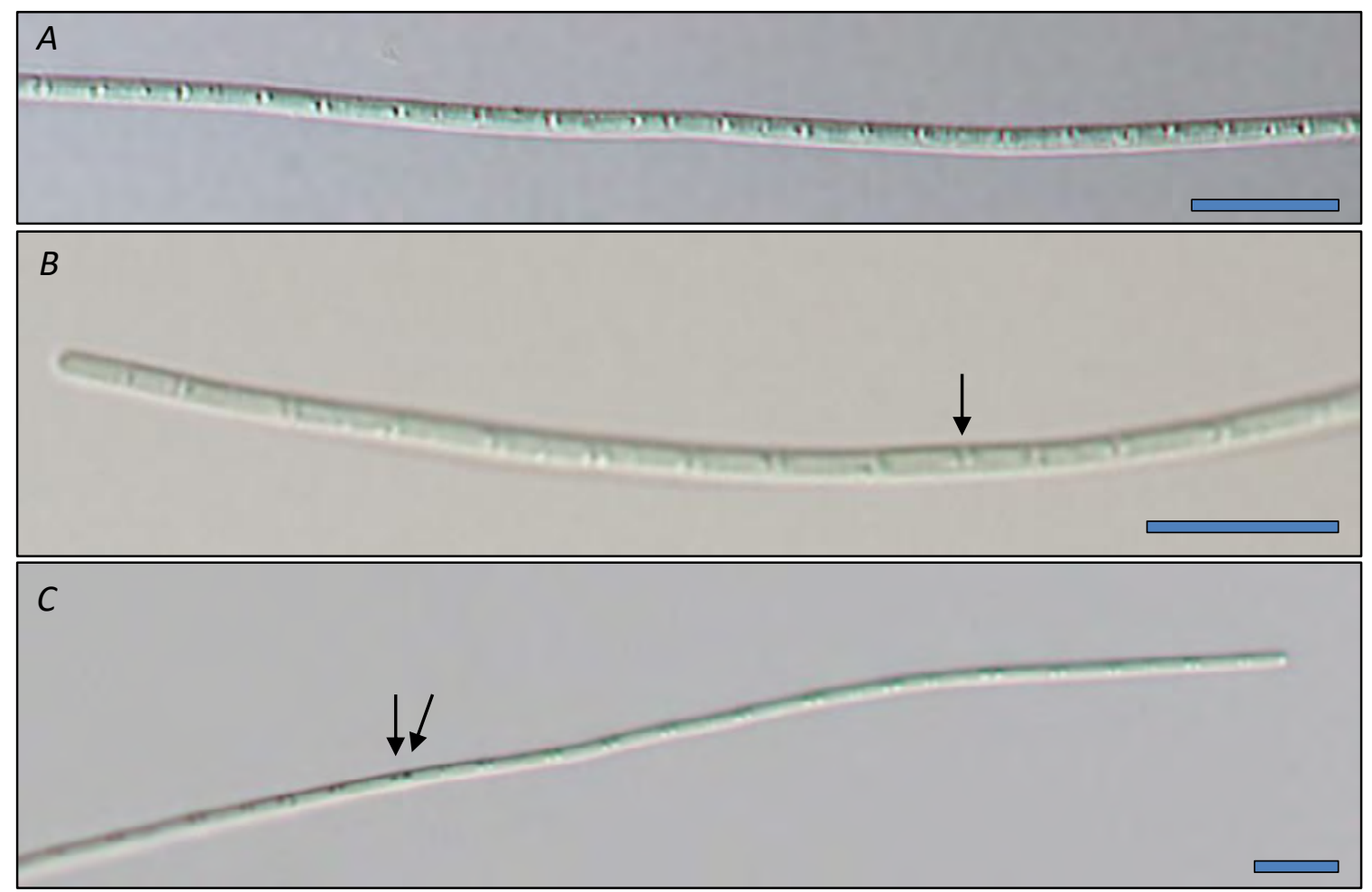

Figure 25. Limnothrix redekei (Van Goor) Meffert; bars are $10 \mu \mathrm{m}$ in length (Komárek and Anagnostidis, 2005, fig. 82).

Figures $25 A-25 C$ illustrate Limnothrix redekei, a filamentous form that is straight to slightly curved. Cells are longer than they are wide, with distinct cross-walls (clear space at arrow) and inclusions adjacent to the cross-wall (double arrow). 
Order Synechococcales

Family Pseudanabaenaceae

Genus Pseudanabaena
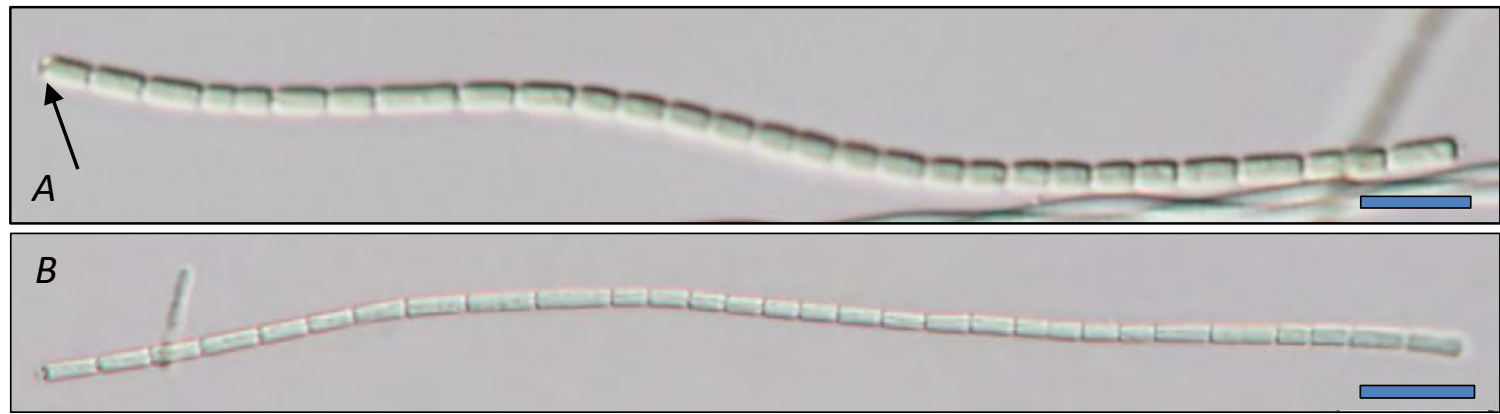

Figure 26. Pseudanabaena cf. galeata Böcher; bars are $10 \mu \mathrm{m}$ in length (Komárek and Anagnostidis, 1998, fig. 67).

Figures $26 A$ and $26 B$ illustrate $P$ seudanabaena cf. galeata, a filamentous form that is slightly curved. Cells are longer than wide, deeply constricted at the cross-walls, and with a distinct terminal cell with a clear inclusion (at arrow). 
Order Synechococcales

Family Pseudanabaenaceae

Genus Pseudanabaena
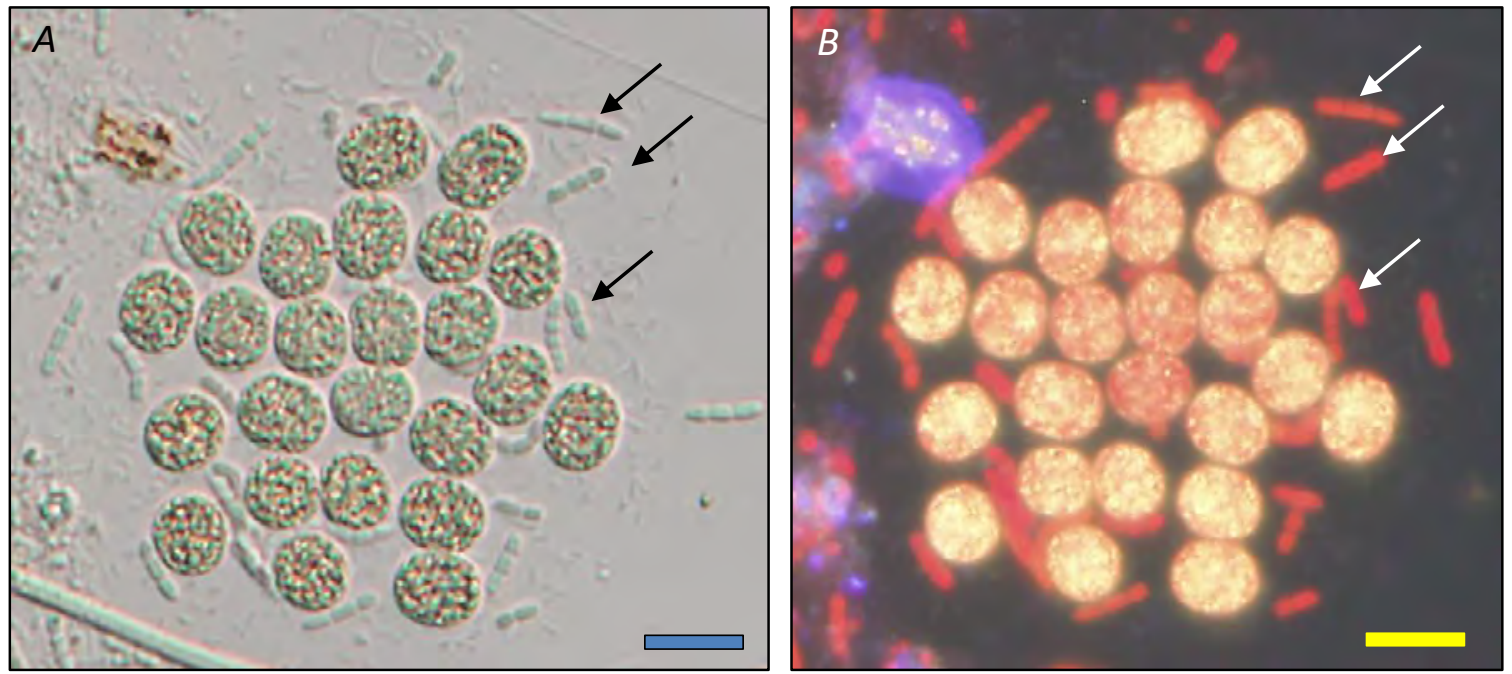

Figure 27. Pseudanabaena mucicola (Naumann and Huber-Pestalozzi) Schwabe (at arrows) in the Microcystis colony; bars are $10 \mu \mathrm{m}$ length (Komárek and Anagnostidis, 2005, fig. 51).

Figures $27 A$ and $27 B$ illustrate Pseudanabaena mucicola (at arrows), a filamentous form that lives in association with Microcystis and other cyanobacteria and algae. Filaments of $P$. mucicola are 2-8 cells long, deeply constricted at the cross-walls, and with a conical terminal. Fig. 27B, illuminated by UV epifluorescence, shows the deep red color of $P$. mucicola, whereas the Microcystis cells appear granular and yellow because of the presence of aerotopes. 
Order Synechococcales

Family Pseudanabaenaceae

Genus Pseudanabaena

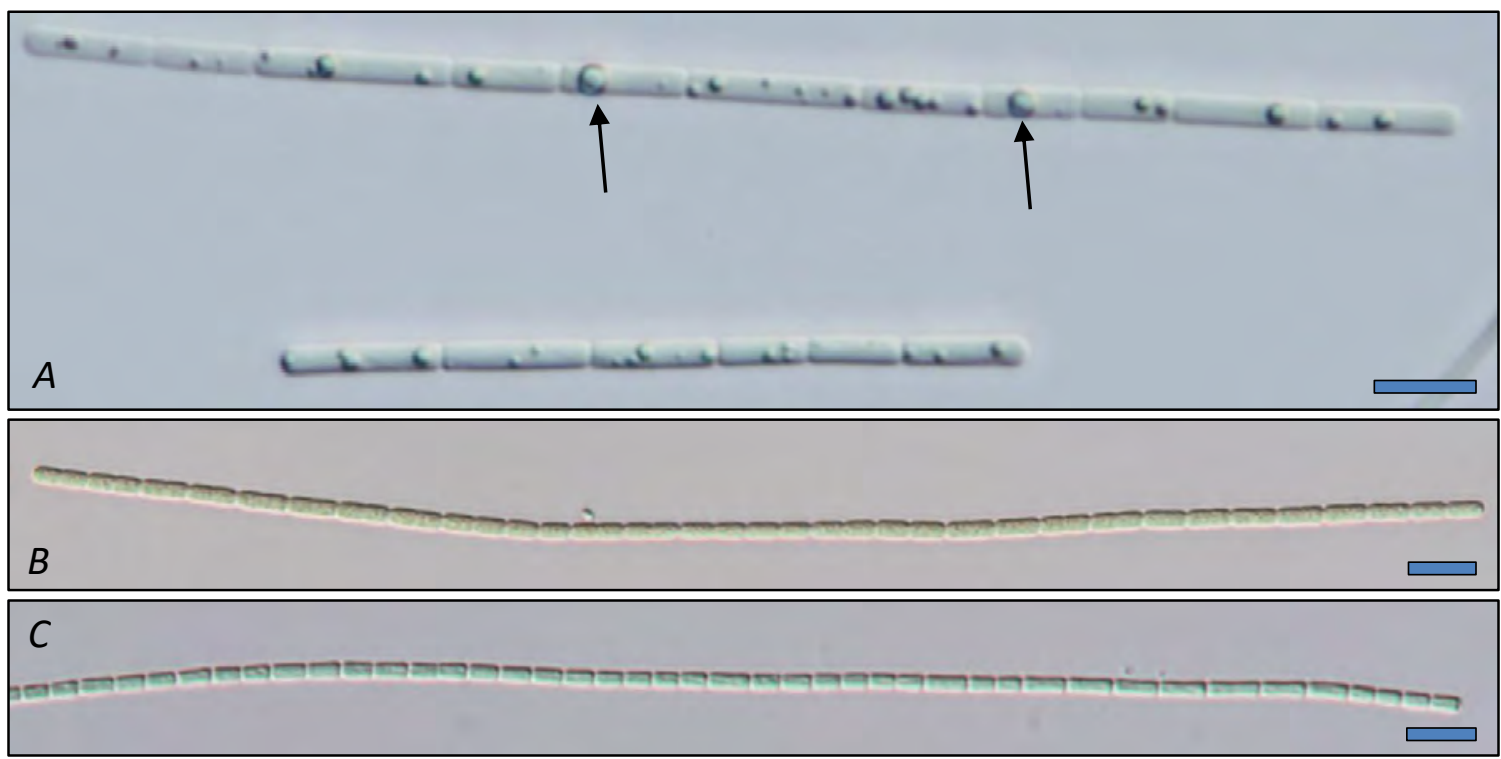

Figure 28. Pseudanabaena sp. Lauterborn; bars are $10 \mu \mathrm{m}$ length (Komárek and Anagnostidis, 2005).

Figures 28A-28C illustrate Pseudanabaena sp., a filamentous form that is straight to slightly curved. Cells are longer than they are wide, deeply constricted at the cross-walls. Fig. 28A shows cellular inclusions (at arrows) that may function as aerotopes. 


\section{References}

Canfield Jr., D.E., and Hoyer, M.V., 1988, The eutrophication of Lake Okeechobee, Lake and Reservoir Management, v. 4, no. 2, p. 91-99.

Davis, T.W., Bullerjahn, G.S., Tuttle, Taylor, McKay, R.M., and Watson, S.B., 2015, Effects of increasing nitrogen and phosphorus concentrations on the growth and toxicity of Planktothrix blooms in Sandusky Bay, Lake Erie: Environmental Science and Technology, v. 49, no. 12, p. 7197-7207.

Davis, T.W., Harke, M.J., Marcoval, M.A., Goleski, Jennifer, Orano-Dawson, Celia, Berry, D.L., and Gobler, C.J., 2010, Effects of nitrogenous compounds and phosphorus on the growth of toxic and non-toxic strains of Microcystis during cyanobacterial blooms: Aquatic Microbial Ecology, v. 61, no. 2 , p.149-162.

Davis, T.W., Berry, D.L., Boyer, G.L., and Gobler, C.J., 2009, The effects of temperature and nutrients on the growth and dynamics of toxic and non-toxic strains of Microcystis during cyanobacteria blooms: Harmful Algae v. 8, no. 5, p. $715-725$.

Gobler, C.J., Burkholder, J.M., Davis, T.W., Harke, M.J., Stow, C.A., and Van de Waal, D.B., 2016, The dual role of nitrogen supply in controlling the growth and toxicity of cyanobacterial blooms: Harmful Algae, v. 54, p. 87 - 97.

Harke, M.J., and Gobler, C.J., 2015, Daily transcriptome changes reveal the role of nitrogen in controlling microcystin synthesis and nutrient transport in the toxic cyanobacterium, Microcystis aeruginosa: BMC Genomics, v. 16, p. 1068, DOI 10.1186/s12864-015-2275-9.

Havens, K.E., Hanlon, Charles, and James, R.T., 1995a, Historical trends in the Lake Okeechobee ecosystem, V. Algal blooms: Archiv fur Hydrobiolgie, Supplement 107, p. $89-100$.

Havens, K.E., Hanlon, Charles, and James, R.T., 1995b, Seasonal and spatial variation in algal bloom frequencies in Lake Okeechobee, Florida, USA: Lake and Reservoir Management, v. 10, p. 139-148.

Havens, Karl, Paerl, Hans, Philips, Edward, Zhu, Mengyuan, and Srifa, Akeapot, 2016, Extreme weather events and climate variability provide a lens to how shallow lakes may respond to climate change: Water, v. 8, no. 6, p. 229-247.

Komárek, Jiří, 1984, Sobre las Cianofíceas de Cuba. 1) Aphanizomenon volzii; 2) Especies de Fortiea: Acta Bot. Cubana, v. 18, p. 1-30

Komárek, Jiří, 2008, The cyanobacterial genus Macrospermum: Fottea, Olomouc, v. 8, no. 1, p. 79-86.
Komárek, Jiř́i, 2013, Süsswasserflora von Mitteleuropa. Cyanoprokaryota-3rd part: heterocystous genera. Heidelberg, Springer Spektrum, Vol. 19 pp. [i]-xviii, [1]-1130.

Komárek, Jiř́ and Anagnostidis, Konstantinos, 1998, Cyanoprokaryota-1. Chroococcales, in Ettl, H., Gärtner, G., Heynig, H. and Mollenhauer, D. eds, Süßwasserflora von Mitteleuropa. Begründet von A. Pascher. Band 19/1: Heidelberg \& Berlin: Spektrum, Akademischer Verlag, p. 1-548.

Komárek, Jiří and Anagnostidis, Konstantinos, 2005, Cyanoprokaryota-2 Süßwasserflora von Mitteleuropa. Teil/2nd Part: Oscillatoriales: München, Elsevier Spektrum Akademischer Verlag, Vol. 19 pp. 1-759.

Komárek, Jiří, Kastovsky, Jan, Mareš, Jan, and Johansen, J.R., 2014, Taxonomic classification of cyanoprokaryotes (cyanobacterial genera) using a polyphasic approach: Preslia, v. 86, p. 295-335.

O’Neil, J.M., Davis, T.W., Burford, M.A., and Gobler, C.J., 2012, The rise of harmful cyanobacteria blooms-The potential roles of eutrophication and climate change: Harmful Algae, v. 14, p. 313-334.

Pearson, L.A., Dittmann, Elke, Mazmouz, Rabia, Ongley, S.E., D'Agostino, P.M., and Neilan, B.A., 2016, The genetics, biosynthesis and regulation of toxic specialized metabolites of Cyanobacteria: Harmful Algae. v. 54, p. 98-111.

Phlips, E.J., Badylak, Susan, Hart, Jane, Haunert, Daniel, Lockwood, Jean, O’Donnell, Kathryn, Sun, Detong, Viveros, Paula, and Yilmaz, Mete, 2012, Climatic influences of autochthonous and allochthonous phytoplankton blooms in a subtropical estuary, St. Lucie Estuary, Florida, USA: Estuaries and Coasts, v. 35, p. 335-352.

Rajaniemi, Pirho, Komárek, Jiří, Hoffmann, Lucien, Hrouzek, Pavel, Kaštovská, Klára, and Sivonen, Kaarina, 2005, Taxonomic consequences from the combined molecular and phenotype evaluation of selected Anabaena and Aphanizomenon strains: Algological Studies, v. 117, p. 371-391.

Reynolds, C.S., 1984, The ecology of freshwater phytoplankton: Cambridge, U.K., Cambridge University Press, $384 \mathrm{p}$.

Rosen, B.H., Loftin, K.A., Smith, C.E., Lane, R.F., and Keydel, S.P., 2010, Microphotographs of cyanobacteria documenting the effects of various cell-lysis techniques: U.S. Geological Survey Open-File Report, 2010-1289, 203 p., https://pubs.usgs.gov/of/2010/1289/pdf/of2010-1289.pdf. 
Rosen, B.H., and St. Amand, Ann, 2015, Field and laboratory guide to freshwater cyanobacteria harmful algal blooms for Native American and Alaska Native Communities: U.S. Geological Survey Open-File Report 2015-1164, 44 p., http://dx.doi.org/10.3133/ofr20151164.

Rosen, B.H., and Mareš, Jan, 2016, Catalog of microscopic organisms of the Everglades, Part 1-The cyanobacteria: U.S. Geological Survey Open-File Report 2016-1114, 108 p., http://dx.doi.org/10.3133/ofr20161114.

Stein, J.R., 1973, Handbook of phycological methods: Culture methods and growth measurements: Cambridge University Press, 448 p.

Visser, P.M., Verspagen, J.M.H., Sandrini, Giovanni., Stal, L.J., Matthijs, H.C.P., Davis, T.W., Paerl, H.W. and Huisman, Jef, 2016, How rising $\mathrm{CO}_{2}$ and global warming may stimulate harmful cyanobacterial blooms: Harmful Algae, v. 54, p. 145-159.

Wacklin, Pirjo, Hoffmann, Lucien, and Komárek, Jiř́í, 2009, Nomenclatural validation of the genetically revised cyanobacterial genus Dolichospermum (Ralfs ex Bornet et Flahault) comb. Nova: Fottea, v. 9, no.1, p. 59-64. 
All images in this publication were taken by Barry H. Rosen

Publishing support provided by Lafayette Publishing Service Center 

